ISSN: 2146-3042

DOI:

\title{
Testing Dividend Signaling Theory in Turkey as an Emerging Market: Empirical Evidence From Public Firms Listed in Borsa Istanbul*
}

\author{
Özgür Kaymaz**
}

Önder Kaymaz ***

Batuhan Güvemli****

\begin{abstract}
Dividends (profit share) and profitability (financial performance) still remain unarguably among the most salient attributes of financial research. This paper is interested in empirically exploring if and how signalization theory works in general while being interested in also exploring to what extent dividends may account for the corporate profitability being corporate financial performance in particular. Dynamic panel regressions are performed to test our predictions on twelve (12) different models for an emerging market economy with a sampling time window spanning 2000 through 2018 for 45 listed companies. Financial firms (FFs) versus Non-Financial firms (NFFs) are examined separately and compared together. Although results usually document that (present) dividends tend to be irrelevant in accounting for (signalling future) corporate profitability. However, we have found evidence that dividends, for NFFs, were documented to be relevant in explaining future corporate profitability when the regressed variable is proxied as Return on Capital which may be captured as Earnings Before Tax/Paid-in Capital. In particular, the relationship between present corporate dividend distribution and future corporate profitability is positive, suggesting the higher (lower) the dividends the higher (lower) the profitability. In addition, of all the models tested, for a sizeable fraction, we have also found significant linkage between the lagged and the leadership values of the dependent variable being corporate profitability or corporate financial performance, either for FFs or NFFs if not both.

Key Words: Signalization Theory, Dividend, Profitability, Financial Performance, Information Content, Value Relevance, Financial Companies, Non-Financial Companies. Borsa Istanbul.

JEL Sinıflandırması: G20, M41.
\end{abstract}

\section{Gelişmekte Olan Bir Piyasa Olarak Türkiye'de Temettü Sinyalleşme Teorisinin Test}

\section{Edilmesi: Borsa İstanbul'da Listelenen Firmalardan Ampirik Kanitlar}

\section{ÖZET}

Temettüler (kar payları) ve karlllık (finansal performans) halen tartısmasız bir șekilde finansal araștırmanın en göze çarpan özellikleri arasındadır. Bu makale, genel olarak sinyalizasyon teorisinin ișe yarayıp yaramadığını ve nasıl çalıștığını ampirik olarak araștırmakla ilgilenirken, ayn zamanda temettülerin özellikle kurumsal finansal performansı ifade eden kurumsal karlllıktan ne ölçüde sorumlu olabileceğini incelemekle ilgilenmektedir. Bu çalışmada dinamik panel regresyonları, gelişmekte olan bir pazar ekonomisi için on iki (12) farklı model üzerindeki tahminlerimizi test etmek üzere, borsada kote edilen 45 sirket örnekleminde 2000'den 2018'e uzanan bir zaman penceresi ile gerceklestirilmektedir. Finansal ve finansal olmayan şirketler ayrı ayrı incelenmekte ve birlikte karşılaştırılmaktadır. Sonuçlar genellikle (mevcut) temettülerin gelecek donemdeki kurumsal karlılığın habercisi olma noktasinda ilgisiz olma eğiliminde olduğınu belgelemektedir. Mamafih; ampirik kantlar, finansal olmayan sirketler için temettülerin, bağıml değiskenin (karlılı̆̆ın) Vergi Öncesi Kazanç / Ödenmis Sermave olarak ölçülebilen "Sermave Getirisi" olması durumunda gelecek donemdeki karlllğ̆ açıkladığını göstermektedir. Özellikle, cari donemdeki temettü dağıtımı ile gelecek donemdeki karlılık arasında pozitif seyreden ilişsi bize kar payları ne kadar yüksek (düşük) ise karlıllğın da o kadar yüksek (düşük) olması anlamına gelmektedir. Buna ek olarak, bu çalıșma, test edilen bütün modellerin büyük bir kismı için, kurumsal karlllkk veva kurumsal finansal performans olarak temsil edilen (ölçülebilen) bağımlı değiş̧enin gecikmeli ve öncü değerleri arasında, finansal şirketler ve/veya finansal olmayan şirketler için, anlamlı bir ilişki olduğunu göstermektedir.

Anahtar Kelimeler: Sinyalizasyon Teorisi, Temettü, Karlllık, Finansal Performans, Bilgi İçeriği, Değer İlgisi, Finansal Şirketler, FinansalOlmayan (Reel) Sirketler. Borsa Istanbul.

Jel Classification: G20, M41.

\footnotetext{
* Bu makale, 23-25 Nisan 2021 tarihleri arasında gerçekleștirilen VI. Uluslararası Muhasebe ve Finans Sempozyumunda bildiri olarak sunulmuștur. Kaymaz (2010) tarafından yazılmış olan yayımlanmamış doktora tezinden türetilmiștir.

Makale Gönderim Tarihi: 08.05.2021, Makale Kabul Tarihi: 26.05.2021, Makale Türü: Nicel Araştırma

** Dr., Turkish Airlines Inc. (THY A.O), okaymaz@thy.com, Empirical Research, ORCID: 0000-0003-12877873. Opinions/views here do not belong to nor represent those of Turkish Airlines Inc.

*** Dr., Clarion University (U.S.), kaymazonder@yahoo.com, Corresponding Author, ORCID: 0000-0001-9875$537 \mathrm{X}$

${ }^{* * * *}$ Dr., Trakya University, bguvemli@yahoo.com, 0000-0002-2985-5198
} 


\section{BACKGROUND AND PRIOR LITERATURE}

Dividend (profit share) policy is the decision that companies use to decide how much they will pay out to shareholders in the form of dividends. In England and Holland, shareholders received both the profit and the capital under the name of initial payment, and these actions removed the existence of joint stock companies. As a result, subsequent payments were limited to net profit. Companies gained eternal lives with the efficient use of investment capital and contractual relations. Despite their controversial nature, dividend payments continue to exist for more than three hundred years as a necessary or reasonable practice (Frankfurter and Wood, 2002: 114).

Dividend signaling theory, free cash flow theory, and clientele effect theory can be given among some significant dividend policies. Fuller and Thakor (2002) suggest that there is little evidence for the validity of clientele effect theory for firms paying dividends. Thus, empirical researchers are more common among signalization and free cash flow theories. Dividend signalization theory suggests that good firms use dividend payouts and stock repurchases to differentiate themselves from bad firms. According to this theory, an increase in dividend payout is considered as an indication of positive prospects. On the other hand, a decrease in dividend payout is regarded as wrong signals, and when there is no dividend payout, no significant change is expected shortly (Khang and Ding, 2009: 5). Hence, according to Valipour et al. (2009), starting or ending dividend payments is of importance for dividend payments is an indicator for measuring future performance.

The most reliable prediction of the signalization theory is probably the monotonic relationship between the manager's knowledge of future earnings and unexpected dividend changes. This prediction is generalized within the framework of a statistical model. The model is used to examine and distinguish the knowledge of the manager from the understanding of the market. Also, a proper firm set needs to be established as well. Signaling occurs when a manager believes that the current value of their company stocks is higher than it should be (Hassan et al., 2003: 2).

Lintner (1956) is considered as the pioneer of dividend policy studies in fact. His fifteen variables include firm size, factory and equipment costs, will of providing an external source, dividend and share usage, earnings stability, ownership of the control group. Brittain (1964 and 1966), Fama and Babiak (1968) reformulated Lintner's model by extracting the constant variable and including deferred earnings. Fama (1974) did the same research with more samples and reached a similar conclusion for dividend policy stability.

Kato and Loewenstein (1995) found that Japanese companies have stable dividend payout policies. Dewenter and Warther (1998) implemented Lintner's model to American and Japanese companies and found that the dividend policies of American administrators (19821993) are straighter than Fama and Babiak’s (1946-1964) findings. Furthermore, they found that Japanese companies cut the dividend payouts and had less stable dividend policies relative to Americans'. Chateau (1979) and Shevlin (1982) applied Lintner's model to Canadian and Australian companies. Similarly, Mcdonald et al. (1975) studied the French stock exchange. Lasfer (1996) used the Lintner's model for panel data analysis to English companies. They implemented these analyses to developed markets, and the typical findings indicate that companies operating at developed markets have stable dividend policies. 
Glen et al. (1995) found significant differences between the dividend policies of developed and developing markets. Their findings indicate that the dividend payout rate of developing countries is the $2 / 3$ of the OECD countries. Moreover, companies in developing markets have target dividend rates, but they do not pursue stable dividend policies. Benartzi et al. (1997) state that dividend policies change when there is continuity at earnings. Thus, they argue that Lintner's model is the finest to explain dividend policy behaviors. They also state that managers tend to decrease dividend payouts when they have less hope for future earnings. DeAngelo and DeAngelo (1990) present that to preserve the corporate image, companies tend to decrease dividend payouts in bad financial conditions rather than cutting payments permanently. Baker et al. (1985) and Pruitt and Gitman (1991) found that managers give much importance to stable dividend policies.

Baryosef and Huffman (1986) show that dividend size is a function of increased future cash flows. Ofer and Thakor (1987) state that firms tend to repurchase their shares when they think the stock prices are undervalued. Their findings also indicate that companies would make dividend payments to correct share prices as well. Brav et al. (2005) contend that there may be other factors influencing share repurchases. According to their research, some managers believe that they could choose the appropriate time for repurchase decisions and know how their decisions would affect earnings per share.

Companies may have different dividend policies. According to Fuller and Thakor (2002) for instance, Coca Cola, Walmart, General Electric, and Florida Power and Light pay a significant number of dividends. On the other hand, CISCO and Microsoft have liquidity surplus because of rather fewer dividend payouts. According to the analysis performed by Fama and French (2001), the percentage of companies paying dividends were 66.5 in 1978. This trend decreased to $20.8 \%$ in 1999 . DeAngelo et al. (2004) state that the stock market is in a balance because of the companies with high dividend payouts. A similar situation exists for special dividends as well. 61.7\% of the companies in NYSE were distributing special dividends at least for once in the 1940s. The trend decreased to 4.9\% in the 1990s (DeAngelo et al., 2000: 310).

Early literature on dividend signaling (e.g. Aharony and Swary, 1980; Denis et al., 1994 etc.) point out that severe share price fluctuations accompany significant changes in dividend policies. These studies indicate that investors perceive companies with higher dividend yields as of better quality. Kane et al. (1984) tested the behaviors of investors to understand their reactions to earnings and dividend payout announcements. Investors tend to trust unexpected dividend increases or decreases more when earnings are below or over expectations. Marsh and Merton (1987) documented that the behavior of dividend payouts is following time series. They also document that companies pay attention to industry payout rates when choosing target dividend payout ratio.

Individual studies (e.g. Watts, 1973; Healy and Palepu, 1988; Brickley, 1983 etc.) have shown reverse and insignificant relations between changes in future earnings and dividends. Ambarish et al. (1987) established a monochromic model for dividends, repurchases, and investments. Williams (1988) redesigned this into a multi-time model and documented that companies tend to make dividend payouts, invest in risky assets, and go to public to maximize company value under efficient signaling composure. 
Sometimes taxation from dividend payouts can surpass the taxation to emanate from share repurchases. Bernheim and Wantz (1992) developed a model for this kind of signaling issues. His model helps companies to control the amount of taxation by working with dividend payouts. Therefore, a firm can choose the optimal taxation rate to give a signal. According to Brooks (1996), dividend announcements do not reduce information asymmetry between traders. However, Laux et al. (1998) argue that dividend announcements may indeed have different impacts in the same industry.

Companies with constant operational cash flow tend to distribute more dividends. However, companies that have temporary and unstable cash flows use stock repurchases as their central dividend policy (Jagannathan et al., 2000: 358). Penman (1983) advocates on the weak signaling relationship between dividends and earnings. Nissim and Ziv (2001) demonstrated that there is a definite correlation between the changes in dividends and changes in earnings over the next two years. According to individual studies (e.g. Benartzi et al., 1997; Grullon et al., 2005 etc.), the correlation between changes in dividends and changes in earnings over the following years conflict with the theory and dividends correlate with current or past earnings. Grullon et al. (2002) show that dividends reflect the risks rather than future earnings.

Allen et al. (2000) united the idea of signaling and taxpayers. They assert that more (less) dividend means more (less) exemption from tax, especially for individual investors. However, this assumption does not work with corporate investors. That is because corporate investors are more successful at choosing the right companies to invest. Nonetheless, Grinstein and Michaely (2005) found a negative correlation between dividend payout rates and corporate ownership. Allen and Michaely (2003) shows that dividend signaling models have two empirical assumptions. The first assumption suggests that changes in share prices accompany unexpected changes in dividends. The second assumption indicates that changes in earnings go along with the changes in dividends. Cited scholars present these findings as supporting pieces of evidence to signaling theory.

Debate on dividend signaling literature continues towards the relations between dividends and earnings over the following years. For instance, Aivazian et al. (2003) shown that dividend payouts in eight developing countries have an unstable structure in comparison with developed capital markets. Glen et al. (1995) indicate that developing countries give much importance to the number of dividend payouts rather than dividend payout rates. These findings show consistency towards the volatility of dividend distribution in developing markets. A study by Adaoglu (2000) shows that dividend signaling indicators diminish because revenues profoundly influence the dividend policies in developing countries.

Chay and Suh's (2005) analysis in twenty-four countries, involving Turkey, reveal significant and a negative relation between dividend payouts and cash flows. Arslan (2008) conducted a survey of 165 executives who work at publicly traded Turkish companies. The survey included questionnaires regarding the opinions of executives towards signaling theories. It was interesting to find that $84 \%$ of the executives considered dividend payouts as a reflection of future expectations. The second highly approved (80\%) issue is that share prices tend to decrease when an unexpected dividend payout occurs. Baker et al. (2007) made a similar questionnaire for the executives of Canadian companies. They found that $89 \%$ of the executives think that it is necessary to inform investors when there is a significant change in 
dividend payment levels. However, only $60 \%$ of the executives in Turkey gave the same straight answer to this topic. In brief, his findings revealed the characteristics of dividend signaling for Turkish publicly traded companies.

Berle and Means (1932) are considered as pioneers for realizing the ineffectiveness of executives when there is a surplus in profitable investments. Their examination provided a basis for the studies of Jensen and Meckling (1976). Their works explain the separation between control and ownership, thus the corporate structure as a result of the works on costing. Inception of risky projects and depletion of sources by executives are considered as one of the leading elements of the agency problem. According to Myers (1977), these problems affect dividend policies in two ways. Significant amounts of dividend payouts to shareholders may cause misuse of capital and rejection of projects with positive net present value (NPV). According to John and Kalay (1982), debt agreements are necessary tools to avoid wealth transfers from lenders to shareholders through dividend payouts.

Jensen (1986) updated free cash flow theory with information asymmetry and agency theory. His work shows how free cash flows can be efficiently used for projects with negative net present values. According to Lang and Litzenberger's (1989) overinvestment hypothesis, an increase in dividend payouts eventually lessens free cash flow problems, disrupts wrong investments and acts as a signal towards an increase in firm value. Similarly, a decrease in dividend payouts also acts as a signal for low firm value. Skilled managers benefit from profitable opportunities and watch over the interests of shareholders. However, should the ownership be separated among individuals, managers then would tend to use resources on risky investments. A conflict of interest occurs between managers and shareholders after all the projects with positive net present value may be financed. Dividend payouts and interest payments eventually decrease the amount of free cash flow (Frankfurter and Wood, 2002: 113).

According to managerial finance theory, internal financing is considered as the critical determinant for investments. Managers can increase the number of investments when there is a possibility for internal financing. Thus, managers act more cautiously when they need to use external financing. Also, when managers rise the number of investments to an abnormal level, the marginal return of these investments would be below the maximum benefit of the shareholder. Agency models consider stock repurchases as more cost-efficient concerning dividend payouts. That is because dividends are decent tools for preventing excess investments resulting from sizeable free cash flows (Sinha et al., 2006: 3).

Grullon et al. (2002) argue that companies with fewer investment opportunities would aim to increase dividend payouts. Chan et al. (2000) shows that companies with higher dividend payout rates hold more cash vis-à-vis the other companies operating within the same industry. DeAngelo and DeAngelo (2006) focused on the trade-off between new supply costs that would incur with dividend payouts and agency costs to incur with retaining profits.

Ellili (2011) examines the interrelationship among corporate financial performance, financial policy, managerial ownership and ownership structure. Managerial ownership is embedded as an endogenous factor into the analyses. Performing a panel regression analysis for a selected sample of 815 firms listed in the U.S. for the period running from 2001 to 2004, scholar shows that stockholders, irrespective of their types, do not tend to possess significant 
portions of stock ownership on the companies with sizable amount of leverage since they run the risk of business failure.

Rehman (2012) studies the determinants underlying corporate dividend distribution rates (DDR). The scholar samples Karachi Stock Exchange in Pakistan for 50 listed firms that declared dividends for the year 2009 and uses OLS regression to test his predictions. He finds that market-to-book value ratio and operating cash flow per share are negatively related to DDR while corporate profitability, current ratio, debt-to-equity ratio as well as corporate tax rates relate to DDR positively. Among the cited factors incorporated into the OLS regressions, market-to-book value, debt-to-equity as well as profitability are shown to be significantly associated with DDR while all the others are documented to be insignificantly accounting for the changes in DDR.

Ajanthan (2013) investigates the association between corporate dividend payout and profitability. Restaurant companies and hotels that are traded in Colombo Stock Exchange (CSE) in Sri Lanka are included in the sample. Scholar performs correlation and regression analyses to test his predictions. He finds that dividends are in fact very relevant to future corporate financial performance and eventually shareholder value, showing that dividends are significantly and positively affiliated with corporate profitability.

Unlike this paper which considers corporate dividends as lead and corporate profitability as lagged variable, Parsian and Koloukhi (2014) investigates the impact of profitability (lead) current ratio and free cash flow on dividend payout (lag) ratio, sampling the public companies quoted on Tahran Stock Exchange (TSE). The scholars perform panel data examination for 102 listed companies and for the time window running from 2005 through 2010. They find that profitability negatively and significantly relates to corporate dividend payout policies, meaning that the higher (lower) the corporate profitability, the lower (higher) the corporate dividend payouts.

Chemmanur and Tian (2014) examines the effect of firm's discretion as for the release of private information that would precede a reduction in corporate future dividend distribution. Scholars coin the release of private information as market preparation and inquire its probably influence in connection with signaling theory. They sample the period from 1982 to 2006, regressing the data from CRSP and Compustat among the others. They document that companies with higher long-term growth opportunities notwithstanding weaker present financial performance tend to release private information vis-à-vis their future dividend cuts more than the other companies.

Mehta (2012) examines the explanatory factors that underlie corporate dividend policy, sampling the listed companies traded in Abu Dhabi Stock Exchange in UAE. Explanatory factors encompasses size, profitability, risk, liquidity and leverage. The sample employed by the scholar considers 44 companies operating in non-financial industry (e.g. energy, real estate, telecommunications, construction, health care etc.) and 149 time series and cross-sections observations for the time window spanning 2005 through 2009. The scholar develops backward multiple regressions and correlational analysis to test his hypotheses in all the five (5) models construed. Proxies for profitability are given as return on assets (ROA), return on equity (ROE) and earnings per share (EPS) while the proxy for size is considered as 
natural log of total assets. Mehta shows that both profitability and size most significantly contribute to corporate dividend payout policy making process.

Hasan et al. (2015) researches the linkage between corporate dividend distribution payout rate (DPR) and corporate profitability. Considering two industries that prove to be pivotal to Pakistan, textile and energy markets, and sampling for the time frame spanning 1996 through 2008, scholars consider return on assets (ROA) and earnings per share (EPS) as the proxies to capture corporate profitability being financial performance. They construct four (4) models and run logarithmic regression to justify the predicted affinity and find a significant relationship (negative rather positive) between DPR and financial performance. They show that the higher (lower) the DPR the lower (higher) the profitability.

Nenu et al. (2018) studies the linkage of capital structure with corporate performance and risk. Scholars sample the listed firms traded in Bucharest Stock Exchange for the sampling period of 2006 through 2016. They run multivariate fixed-effects regressions along with dynamic panel model with two steps as a GMM (generalized method of moments) estimator. They consider both the dividend distribution rate and profitability as the factors contributing to corporate capital structure and document that leverage is related positively to firm size and stock price volatility both.

Having said these, this paper which is comprised of four (4) sections is interested in exploring if and how signalization theory works in general while being interested in also exploring to what extent dividends may account for the corporate profitability being corporate financial performance in particular. The remainder of this paper is hence organized as follows. Next section, Section 2, presents the empirical data and methodology. Section 3 provides the empirical results and discusses them. Section 4 being the last section concludes this paper.

\section{EMPIRICAL ANALYSIS: DATA AND METHODOLOGY}

Our sample includes the leading 45 (forty-five) public companies that are listed at BIST (Borsa Istanbul, formerly known as ISE being Istanbul Stock Exchange), in Turkey as an emerging market. Istanbul is the financial center (capital) in Turkey where BIST is the main and only equities and debt market (both primary and secondary). The financial data that is used in this investigation belongs to corporate financial statements and was primarily collected from the own website of Borsa Istanbul or websites of listed companies when needed. ${ }^{1}$

The sampling period is considered to run from 2000 through 2018. For individual companies that have no group affiliates solo financial statements are used while for group companies with affiliated or related firms within consolidated financial statements are referenced for data collection. ${ }^{2}$ Since listed companies were mandated to disclose their financial statements in accordance with the IFRSs (International Financial Reporting Standards) after 2006 going forward, this conversion from rule-based reporting (i.e. Turkish

\footnotetext{
${ }^{1}$ Please see also mynet’s URL (http:@finans.mynet.com/) for some additional information that was used in this study as a data collection reference.

${ }^{2}$ This was also the only option that was presented to us for data availability.
} 
GAAP (Generally Accepted Accounting Principles)) to principle-based (IFRS) reporting is generously considered for the purposes of enriched data collection and rigor analysis.

Although we initially considered the leading 50 (fifty) companies to perform our examination, those that were acquired or consolidated otherwise, ceased to operate, was quoted to BIST somewhere in the sampling window, or those that distributed none or no more than one dividend were precluded from the sample for assuring consistency pattern. Since this paper aims to find out if, how or to what extent signalization theory works, sampled listed firms were categorized into two groups, meaning financial firms (FFs) and non-financial firms (NFFs), so that it would be possible to specifically find out to what extent dividends account for corporate profitability, if they do at all. Financial companies include commercial (deposit) banks, insurance companies and real investment trusts (REITs) that were included in top 45 public companies selected for our analyses. Therefore, our two main hypotheses are that:

$\mathbf{H}_{1}$ : There is a relationship between present corporate dividend distribution (payout) and future corporate profitability

H2: Higher (lower) present corporate dividend distribution signals higher (lower) future corporate profitability

Dynamic panel analysis is performed to test our predictions and to best capture the group comparison along with temporal and cross-sectional dimensions concomitantly. Next subsection delves into empirical variables used and empirical model followed in this study.

\subsection{Empirical Variables And Empirical Model}

As given before several times, this examination is interested in seeing if, how or to what extent signalization theory works in general while being interested in also understanding to what extent dividends account for the corporate profitability (corporate financial performance) in particular. Therefore, cash dividend distribution listed companies made is considered as an independent regressor or factor. For the reasons of robustness, a large vector of (dependent) variables that are regressed on cash dividend is considered to capture corporate profitability. To control for any group differences that may exist within the sample distribution, listed firms are categorized into two as FFs and NFFs. 
Table 1. Variables Construction

\begin{tabular}{|c|c|c|}
\hline A. VARIABLE & B. DEFINITION & C. CALCULATION \\
\hline $\begin{array}{l}\text { Independent (Explanatory) } \\
\text { Variable (Regressor): CASH } \\
\text { DIVIDEND PAYOUT }\end{array}$ & $\begin{array}{l}\Delta \text { CASH DIVIDEND: \%Change in Cash } \\
\text { Dividend Paid Out }\end{array}$ & $\begin{array}{c}\text { (Cash Dividend } \mathrm{t}_{\mathrm{t}} \text {-Cash } \\
\left.\text { Dividend }_{\mathrm{t}-1}\right) / \text { Cash Dividend } \\
\\
1\end{array}$ \\
\hline \multirow{12}{*}{$\begin{array}{c}\text { DEPENDENT (REGRESSED) } \\
\text { VARIABLES }\end{array}$} & $\begin{array}{l}\text { 1. } \triangle \text { ROA1: } \% \text { Change in Return on } \\
\text { Assets (= \% Change in Earnings Before } \\
\text { Tax/Total Assets) }\end{array}$ & $\left(\mathrm{ROA} 1_{t+1}-\mathrm{ROA}_{\mathrm{t}}\right) / \mathrm{ROA}_{\mathrm{t}}$ \\
\hline & $\begin{array}{l}\text { 2. } \triangle \text { ROA1ABS: Change (\%) in Return } \\
\text { on Assets }\end{array}$ & ROA1ABS $_{t+1}-$ ROA1ABS $_{t}$ \\
\hline & $\begin{array}{l}\text { 3. } \triangle \text { ROA2: } \% \text { Change in Return on } \\
\text { Assets (= \% Change in Operating } \\
\text { Profit/Total Assets) }\end{array}$ & $\left(\mathrm{ROA} 2_{\mathrm{t}+1}-\mathrm{ROA} 2_{\mathrm{t}}\right) / \mathrm{ROA} 2_{\mathrm{t}}$ \\
\hline & $\begin{array}{l}\text { 4. } \triangle \text { ROA2ABS: Change (\%) in Return } \\
\text { on Assets }\end{array}$ & $\mathrm{ROA}_{2} \mathrm{ABS}_{\mathrm{t}+1}-\mathrm{ROA} \mathrm{ABS}_{\mathrm{t}}$ \\
\hline & $\begin{array}{l}\text { 5. } \triangle \text { ROC1: \% Change in Return on } \\
\text { Capital }(=\% \text { Change in Earnings Before } \\
\left.\text { Tax/Paid-in } \text { Capital }^{3}\right)\end{array}$ & $\left(\mathrm{ROC1}_{\mathrm{t}+1}-\mathrm{ROC} 1_{\mathrm{t}}\right) / \mathrm{ROC}_{\mathrm{t}}$ \\
\hline & $\begin{array}{l}\text { 6. } \triangle \text { ROC1ABS: Change (\%) in Return } \\
\text { on Capital }\end{array}$ & ROC1ABS $_{t+1}-$ ROC1ABS $_{t}$ \\
\hline & $\begin{array}{l}\text { 7. } \triangle \text { ROC2: } \% \text { Change in Return on } \\
\text { Capital (= \% Change in Operating } \\
\text { Profit/Paid-in Capital) }\end{array}$ & $\left(\mathrm{ROC}_{\mathrm{t}+1}-\mathrm{ROC} 2_{\mathrm{t}}\right) / \mathrm{ROC}_{\mathrm{t}}$ \\
\hline & $\begin{array}{l}\text { 8. } \triangle \text { ROC2ABS: Change (\%) in Return } \\
\text { on Capital }\end{array}$ & ROC $2 A B S_{t+1}-$ ROC$^{2} \mathrm{ABS}_{\mathrm{t}}$ \\
\hline & 9. $\triangle \mathrm{OP}: \%$ Change in Operating Profit & $\left(\mathrm{OP}_{\mathrm{t}+1-}-\mathrm{OP}_{\mathrm{t}}\right) / \mathrm{OP}_{\mathrm{t}}$ \\
\hline & $\begin{array}{l}\text { 10. } \triangle \mathrm{EBT} \text { : \% Change in Earnings Before } \\
\text { Tax }\end{array}$ & $\left(\mathrm{EBT}_{\mathrm{t}+1}-\mathrm{EBT}_{\mathrm{t}}\right) / \mathrm{EBT}_{\mathrm{t}}$ \\
\hline & $\begin{array}{l}\text { 11. } \triangle \text { EPS: \% Change in Earnings Per } \\
\text { Share (=\% Change in Net Profit After } \\
\text { Tax/Number of Shares) }\end{array}$ & $\left(\mathrm{EPS}_{\mathrm{t}+1}-\mathrm{EPS}_{\mathrm{t}}\right) / \mathrm{EPS}_{\mathrm{t}}$ \\
\hline & $\begin{array}{l}\text { 12. } \triangle \text { EPSABS: Change }(\%) \text { in Earnings } \\
\text { Per Share }\end{array}$ & $\mathrm{EPS}_{\mathrm{t}+1}-\mathrm{EPS}_{\mathrm{t}}$ \\
\hline
\end{tabular}

\footnotetext{
${ }^{3}$ Paid-in Capital is also known as Contributed Capital, Shared Capital, or Paid-Up Capital in the literature and used interchangeably.
} 
Table 1 above summarizes the set of all the variables used in this empirical examination. As to be seen, cash dividend distribution is the only independent or explanatory variable in the empirical analysis. Percentage (\%) change in cash dividend distribution is used as a proxy to capture cash dividend. It allows us to investigate the direct linkage of dividends with corporate profitability. Twelve (12) different variables are used as proxies each to capture corporate profitability and all of them are constructed in relative (\%) terms in an attempt to control for any extremes, abnormalities or cyclical differences in the observation series and to be consistent with the regressing (independent) factor. Since one independent factor alone is used for all twelve dependent factors exclusively, there are twelve (12) models analyzed in this paper.

The subscripts $t, t+1$ and $t-1$ above stands for current period, future period and past period respectively. Transitions among temporal dimensions allow us to duly consider lags or leads that are argued and hypothesized to be extant between dependent and independent variables. Since the variables such as ROA (ROA1 and ROA2), ROC (ROC1 and ROC2) or EPS are already given in percentages, absolute difference values of the percentages for those variables are also constructed and tested in the empirical investigations to add more variety and thereby richness to the analyses in this paper. ${ }^{4}$ It is also important to note that earnings before tax (EBT) is considered instead of Net Profit After Tax (NPAT) or Net Income in the variables such as ROA1, ROC1 due to several reasons. First, tax is irrelevant in the measurement of corporate profitability. Second, consideration and application of NPAT would be redundant anyway owing to the complex and unnecessarily broad definition of comprehensive income, especially after the inception of IFRSs that were started to be implemented worldwide.

Since this paper tests signalization theory by applying it to an emerging market like Turkey, empirical analyses are made to see if or how dividends account for the corporate profitability. As to be followed from the table above, the independent variable in our model, percentage change in cash dividends paid, is a lead variable while all the dependent variables are lag variables. In other words, we want to see the impact of the cash dividends paid in the preceding periods on the pattern of corporate profitabilities in the following periods. This time lag is considered to be one full fiscal year.

Dynamic panel analyses with one step results are performed to best capture the group comparison along with temporal and cross-sectional dimensions concomitantly, so that any relationship between cash dividend paid out and corporate profitability can be reliably measured and thoroughly examined. Arellano-Bond dynamic panel-data estimation which is a GMM (generalized method of moments) estimator is used. ${ }^{5}$ Group difference is controlled by

\footnotetext{
${ }^{4}$ For instance, in the definition column (Column B) in the above table, the first (1) variable is $\triangle \mathrm{ROA} 1 . \Delta \mathrm{ROA} 1$ means percentage change in Return on Assets which is measured as Earnings Before Tax / Total Assets and calculated as $\left(\mathrm{ROA} 1_{\mathrm{t}+1}-\mathrm{ROA} 1_{\mathrm{t}}\right) / \mathrm{ROA} 1_{\mathrm{t}}$. An example: $(5 \%-2 \%) / 2 \%$, or $1.5 \%$ or 0.015 . The second (2) variable there is $\triangle \mathrm{ROA} 1 \mathrm{ABS}$ which means percentage change in Return on Assets. It is measured as Earnings Before Tax / Total Assets and calculated as ROA1ABS ${ }_{t+1}-\mathrm{ROA}_{1} \mathrm{ABS}_{\mathrm{t}}$. An example: $5 \%-2 \%$, or 3\% or 0.03 . As to be seen, the result is still in percentages.

${ }^{5}$ See for instance Arellano and Bond (1991) who has developed the dynamic panel analysis or refer to Mileva (2007) and so on.
} 
dummy variable being 1 for financial companies and 0 for non-financial companies. The panel regression model is thus specified as:

$$
\mathrm{Y}_{\mathrm{it}}=\omega \mathrm{Y}_{\mathrm{i}(\mathrm{t}-1)}+\Theta \mathrm{X}_{\mathrm{it}-1}+\varepsilon_{\mathrm{it}}
$$

where the terms have obvious meaning. In particular, $\mathrm{Y}$ being the regressed (dependent) variable stands for [percentage (\%) change in] corporate profitability with lead (t) and lagged $(\mathrm{t}-1)$ values and $\mathrm{X}$ being the regressor or explanatory variable refers to [percentage (\%) change in] present corporate (cash) dividend distribution. The next section presents empirical analyses' results and discusses them all.

\section{EMPIRICAL ANALYSIS: RESULTS AND DISCUSSION}

The table below, Table 2, presents the descriptive statistics. Panel A shows the results for the sampled listed financial companies (FFs) and Panel B shows those for non-financial companies (NFFs). Observations, means, standard deviations, minima and maxima are displayed. We see that on average, fluctuation (deviation) in the amount of [percentage change in] cash dividend distribution is higher in NFFs than that of FFs. Likewise, standard deviation and maximum amount of percentage change in cash dividend distribution is also higher in NFFs than those in FFs. The fact that the extent of standard deviation in the case of FFs is significantly lower than that under NFFs shows that cash dividend distributions happened to be more smooth and consistent in the case of FFs.

TABLE 2. Descriptive Statistics: All The Variables

\begin{tabular}{|c|c|c|c|c|c|}
\hline PANEL A. FIN & $\mathrm{CO}$ & PANIES (F & & & \\
\hline Variable | & Obs & Mean & Std. Dev. & Min & $\operatorname{Max}$ \\
\hline$\triangle C A S H D I V I D E N D \circ$ & 132 & .1567427 & 1. 746177 & -5.421738 & 12.11481 \\
\hline$\triangle \mathrm{ROA} 1$ & 210 & 1.778651 & 39.21381 & -132.2523 & 535.2976 \\
\hline$\triangle \mathrm{ROA} A \mathrm{ABS}$ & 211 & -.000407 & .1041755 & -.6719664 & .5635527 \\
\hline$\triangle \mathrm{ROA} 2$ & 207 & 4.897036 & 51.312 & -88.63282 & 566.4908 \\
\hline$\triangle \mathrm{ROA} 2 \mathrm{ABS}$ & 207 & .2870515 & 4.058475 & -17.22033 & 38.6204 \\
\hline$\triangle \mathrm{ROC1}$ & 202 & -.400587 & 77.15241 & -486.6759 & 689.6196 \\
\hline$\triangle \mathrm{ROC} 1 \mathrm{ABS}$ & 202 & $-2.04 \mathrm{e}-\odot 9$ & $4.32 \mathrm{e}-07$ & $-4.06 e-06$ & $4.02 e-06$ \\
\hline$\triangle \mathrm{ROC2}$ & 202 & -.400587 & 77.15241 & -486.6759 & 689.6196 \\
\hline$\triangle \mathrm{ROC} 2 \mathrm{ABS}$ & 202 & $-2.04 \mathrm{e}-\odot 9$ & $4.32 \mathrm{e}-07$ & $-4.06 e-06$ & $4.02 \mathrm{e}-06$ \\
\hline$\triangle O P$ & 197 & -6.057961 & 63.66593 & -593.5879 & 416.0365 \\
\hline$\triangle E B T$ & 197 & -6.057961 & 63.66593 & -593.5879 & 416.0365 \\
\hline$\triangle E P S$ & 180 & 5175.357 & 69268.73 & -3.451913 & 929349.2 \\
\hline$\triangle \mathrm{EPSABS}$ & 228 & $9.55 e-17$ & 40.79866 & -336.824 & 375.4571 \\
\hline
\end{tabular}

PANEL B. NON-FINANCIAL COMPANIES (NFFs)

\begin{tabular}{|c|c|c|c|c|c|c|}
\hline Variable | & | & Obs & Mean & Std. Dev. & Min & $\operatorname{Max}$ \\
\hline \multicolumn{7}{|c|}{ - - - - - - - - - - - - - - - - - - - - - - - - - - - - - - - - - - - - - - - - - - - - - - } \\
\hline$\triangle C A S H D I V I D E N D$ & 1 & 358 & 23.55797 & 146.6299 & -1 & 1530.856 \\
\hline$\triangle \mathrm{ROA} 1$ & | & 570 & -3977.14 & 112231.9 & - 2650971 & 385341.1 \\
\hline$\triangle \mathrm{ROA} 1 \mathrm{ABS}$ & | & 570 & $.0 \odot \odot 4536$ & 5.750193 & -96.27335 & 96.22881 \\
\hline$\triangle \mathrm{ROA} 2$ & | & 570 & 138.7622 & 2134.039 & -55.76207 & 36020.52 \\
\hline$\triangle \mathrm{ROA} 2 \mathrm{ABS}$ & | & 570 & 1.897805 & 107.8012 & -1692.229 & 1530.066 \\
\hline$\triangle R O C 1$ & | & 572 & -6029.709 & 161955.7 & -3851319 & 406499 \\
\hline$\triangle \mathrm{ROC} 1 \mathrm{ABS}$ & | & 581 & .0277687 & 52.40805 & -671.8764 & 671.0693 \\
\hline$\triangle \mathrm{ROC} 2$ & | & 572 & 135.2349 & 2141.416 & -65.71221 & 39126.47 \\
\hline$\triangle \mathrm{ROC} 2 \mathrm{ABS}$ & | & 581 & .0231583 & 2442.76 & -29052.74 & 32847.07 \\
\hline$\triangle O P$ & 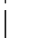 & 583 & 151.2352 & 2391.798 & -149.0549 & 41979.8 \\
\hline$\triangle E B T$ & & 583 & -5917.348 & 160419.9 & -3851319 & 406499 \\
\hline$\triangle E P S$ & i & 574 & 9616.586 & 189917.3 & -53.35602 & 4440340 \\
\hline$\triangle \mathrm{EPSABS}$ & | & 625 & $-1.06 e-07$ & 1357.491 & -23975.15 & 23977.83 \\
\hline
\end{tabular}


Table 2 above also documents that maximum value in cash dividend distribution in FFs belong to $\triangle E P S$ variable being the percentage in earnings per share while the minimum value goes to $\triangle \mathrm{OP}$ being percentage change in operating profits and $\triangle \mathrm{EBT}$ being percentage change in earnings before tax. For NFFs, it provides that maximum value in cash dividend distribution also belong to $\triangle \mathrm{EPS}$ variable while the minimum value goes to $\triangle \mathrm{ROC} 1$ being percentage change in return on capital and $\triangle \mathrm{EBT} .^{6}$

Table 3 below shows the relationship between dividends and corporate profitability (financial performance) where the dependent being the regressed factor is the percentage change in return on assets being $\triangle$ ROA1. Earnings before tax is in the numerator in the formula. This can be considered as Model 1. In particular, Panel A and Panel B show the linkage of cash dividends with profitability for FFs and NFFs respectively. In Panel A, the correlation coefficient of $\triangle$ CASHDIDIVEND (.0844893) and $p$ value $(67.5 \%)$ both being marked in bold suggest that there is a positive (the higher [the lower] the dividends the higher [the lower] the profitability), but insignificant relationship between dividend distribution and profitability. The overall model in Panel A does not significantly document any relationship between dividends and profitability either since $\mathrm{p}$ value (60.68\%), as marked in bold, greatly exceeds even 10\% (90\% confidence interval). On the other hand, Panel B does document a robust model where p value (2.99\%), as marked in bold also, is lower than $5 \%$ and thus significant at $5 \%$. It shows that the linkage between lagged ( $\triangle$ ROA1L1) and lead $(\triangle \mathrm{ROA} 1)$ values of the dependent variable being corporate profitability, as given by the $p$ value being $0.8 \%$, is very significant. It also documents that dividend distribution positively relates to profitability where the correlation coefficient is .004933 . However, the $\mathrm{p}$ value there being $90.2 \%$ is insignificant there. Therefore, neither in FFs nor in NFFs, cash dividends do not account for the changes in the profitability being financial performance. ${ }^{7}$

Table 3. Dividend-Profitability Relationship: Model 1

Dependent (Regressed) Variable: $\triangle$ ROA1\%

Independent Variable (Regressor): $\Delta$ Cash Dividend\%

PANEL A. FINANCIAL COMPANIES (FFs)

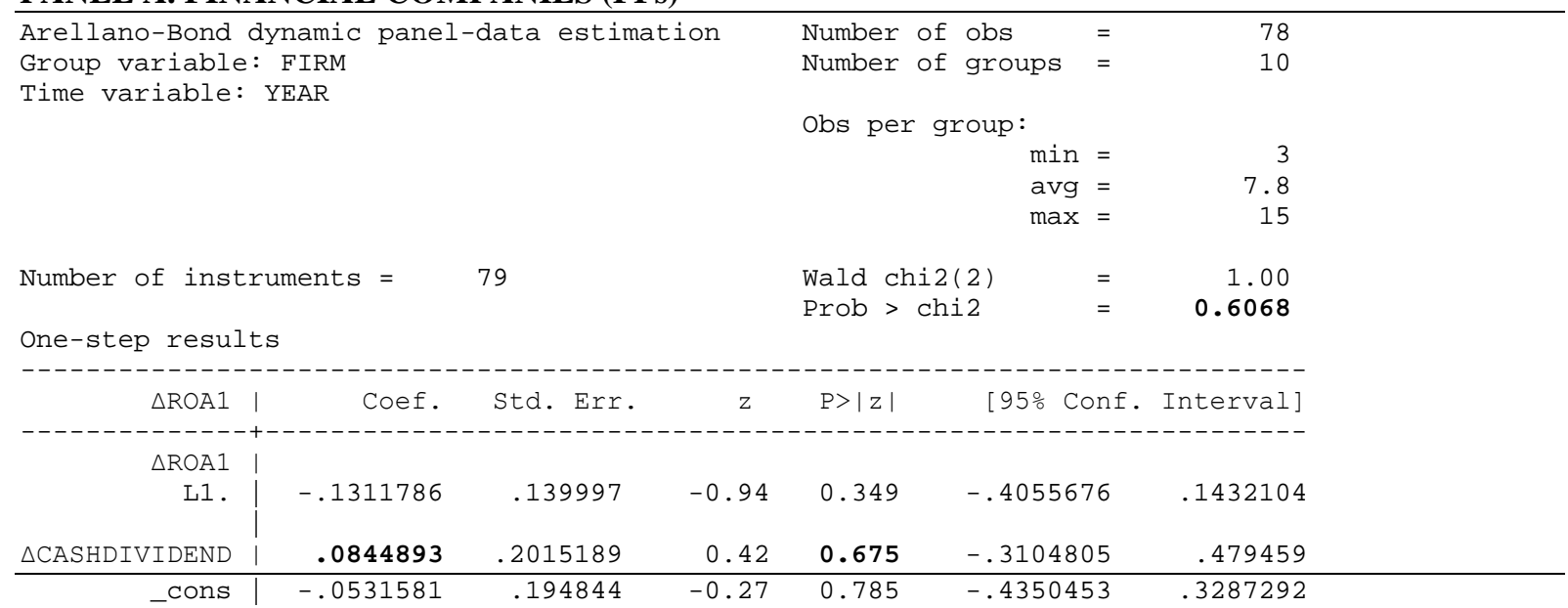

\footnotetext{
${ }^{6}$ Relevant numbers/variables are highlighted in bold and italic in the table.

${ }^{7}$ The superscripts ***, ** and * refer to " very significant (significant at 1\%) ", “ significant (significant at 5\%)

” and “ little or poorly or weakly significant (significant at 10\%)” significance levels respectively.
} 


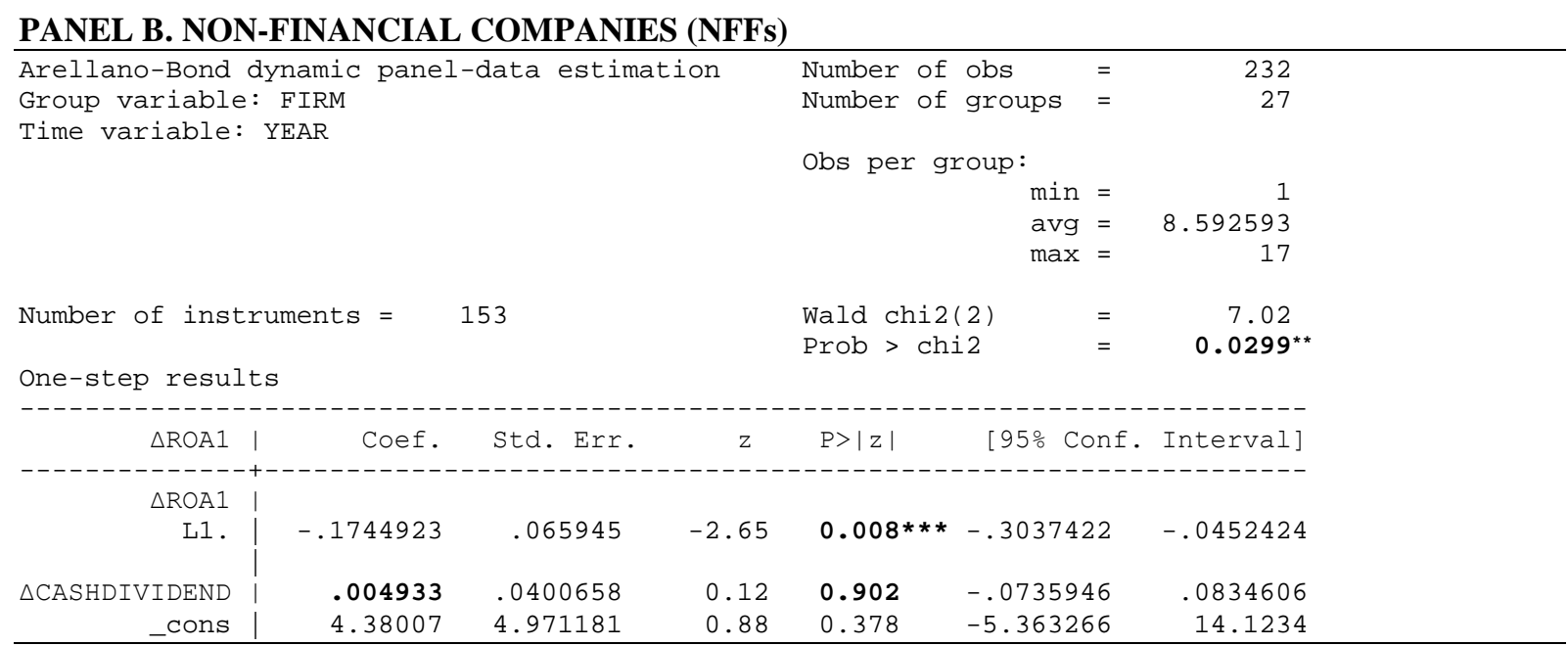

Table 4 below shows the relationship between dividends and corporate profitability where the dependent being the regressed factor is the absolute difference values of the percentages in return on assets being $\triangle \mathrm{ROA} 1 \mathrm{ABS}$. Earnings before tax is in the numerator in the formula. This can be considered as Model 2. In particular, Panel A and Panel B show the linkage of cash dividends with profitability for FFs and NFFs respectively. In Panel A, the correlation coefficient of $\triangle$ CASHDIDIVEND (-.0010503) and p value (83.4\%) both being marked in bold suggest that there is a negative (the higher [the lower] the dividends the lower [the higher] the profitability), but insignificant relationship between dividend distribution and profitability. The overall model in Panel A does not significantly document any relationship between dividends and profitability either since p value (95.78\%), as marked in bold, greatly exceeds even 10\% (90\% confidence interval). On the contrary, Panel B documents a robust model where $\mathrm{p}$ value $(0.00 \%)$, as marked in bold also, is even less than $1 \%$ and thus very significant. It shows that the linkage between lagged ( $\triangle$ ROA1ABSL1) and lead $(\triangle \mathrm{ROA} 1 \mathrm{ABS})$ values of the dependent variable being corporate profitability, as given by the p value being $0.00 \%$, is very significant. Similar to Panel A, the correlation coefficient being 0.0001788 shows that dividend distribution is negatively associated with profitability. However, the p value being there being $94.2 \%$ is insignificant there. Therefore, neither in FFs nor in NFFs, cash dividends do not account for the changes in the profitability being financial performance.

Table 4. Dividend-Profitability Relationship: Model 2

Dependent (Regressed) Variable: $\triangle$ ROA1ABS\%;

Independent Variable (Regressor): $\Delta$ Cash Dividend $\%$

PANEL A. FINANCIAL COMPANIES (FFs)

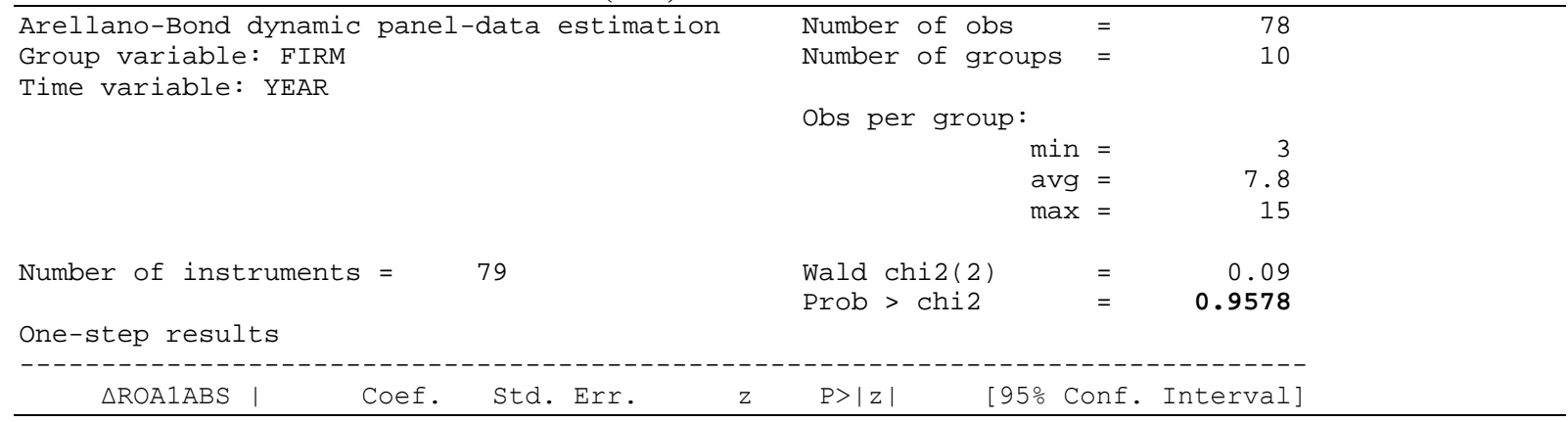




\begin{tabular}{|c|c|c|c|c|c|c|}
\hline \multicolumn{7}{|c|}{ - - - - - - - - - - - + - - - - - - - - - - - - - - - - - - - - - - - - - - - - - - - - - - - - - - - - - - - - } \\
\hline L1. & -.0373268 & .1811864 & -0.21 & 0.837 & -.3924456 & .3177919 \\
\hline$\triangle$ CASHDIVIDEND & -.0010503 & .0050145 & -0.21 & 0.834 & - . 0108786 & .008778 \\
\hline _cons & -.002531 & $.0 \odot 47494$ & -0.53 & 0.594 & - . 0118397 & .0067777 \\
\hline
\end{tabular}

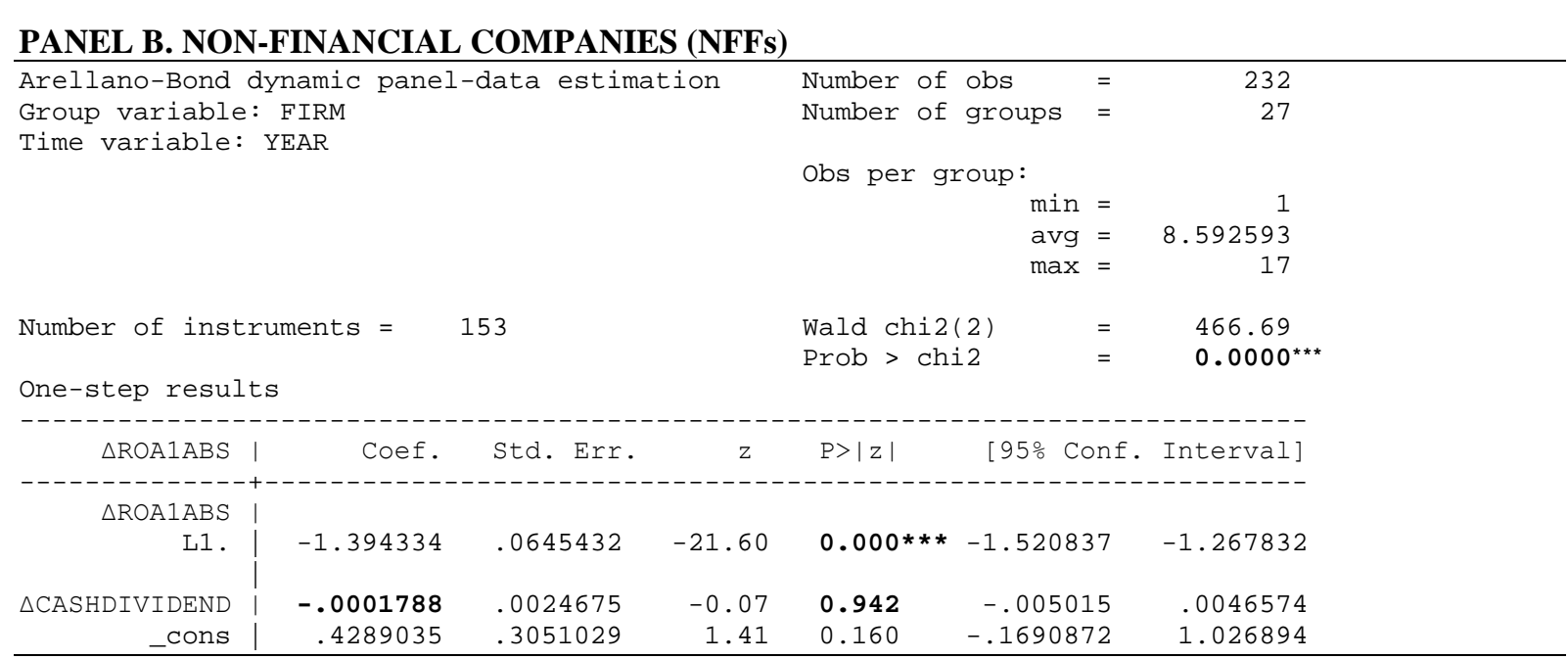

Table 5 below shows the relationship between dividends and corporate profitability where the dependent being the regressed factor is the percentage change in return on assets being $\triangle$ ROA2. Operating profit is in the numerator in the formula. This can be considered as Model 3. In particular, Panel A and Panel B show the linkage of cash dividends with profitability for FFs and NFFs respectively. In Panel A, the correlation coefficient of $\triangle$ CASHDIDIVEND (.395064) and $\mathrm{p}$ value $(87.3 \%)$ both being marked in bold suggest that there is a positive, but insignificant relationship between dividend distribution and profitability. The overall model in Panel A does not significantly document any relationship between dividends and profitability either since $\mathrm{p}$ value (54.15\%), as marked in bold, greatly exceeds even 10\% (90\% confidence interval). Likewise, Panel B documents a non-robust model where p value (98.65\%), as marked in bold also, way exceeds $10 \%$ and thus too insignificant. Similar to Panel A, the correlation coefficient being -0.1056555 shows that dividend distribution is negatively associated with profitability. However, the p value being there being 89.5\% is insignificant there. Therefore, neither in FFs nor in NFFs, cash dividends do not account for the changes in the profitability being financial performance.

Table 5. Dividend-Profitability Relationship: Model 3

Dependent (Regressed) Variable: $\triangle$ ROA2\%;

Independent Variable (Regressor): $\Delta$ Cash Dividend\%

PANEL A. FINANCIAL COMPANIES (FFs)

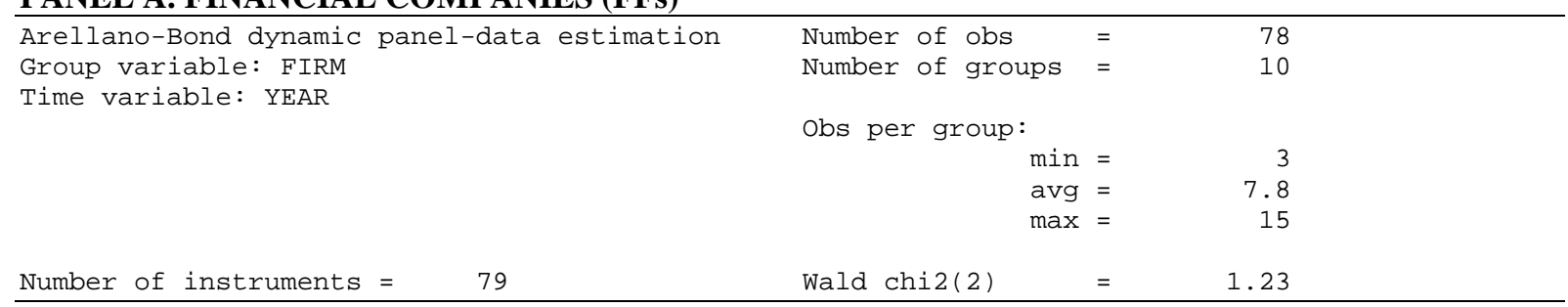




\begin{tabular}{|c|c|c|c|c|c|c|}
\hline \multicolumn{7}{|l|}{ One-step results } \\
\hline \multicolumn{7}{|c|}{ 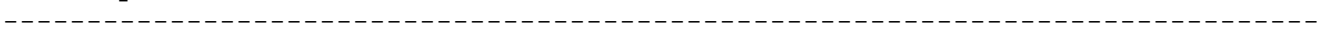 } \\
\hline$\triangle \mathrm{ROA} 2 \quad \mid$ & Coef. & Std. Err. & z & $\mathrm{P}>|\mathrm{z}|$ & {$[95 \%$ Conf. } & Interval] \\
\hline \multicolumn{7}{|c|}{ 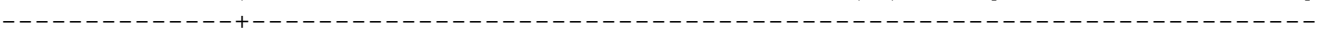 } \\
\hline$\triangle \mathrm{ROA} 2 \quad \mid$ & & & & & & \\
\hline L1. I & -2.295706 & 2.131778 & -1.08 & 0.282 & -6.473915 & 1.882503 \\
\hline$\triangle$ CASHDIVIDEND & .395064 & 2.476334 & 0.16 & 0.873 & -4.458462 & 5.248589 \\
\hline _cons | & -.7880217 & 4. 247941 & -0.19 & 0.853 & -9.113834 & 7.537791 \\
\hline
\end{tabular}

\section{PANEL B. NON-FINANCIAL COMPANIES (NFFs)}

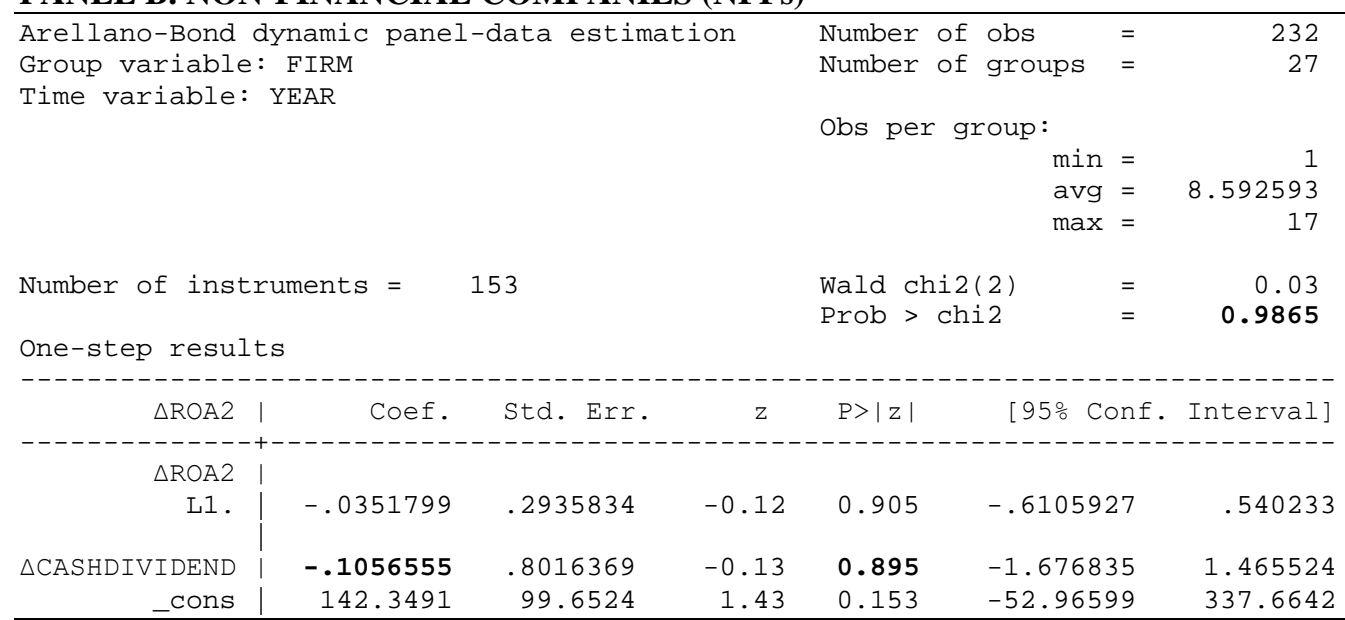

Table 6. Dividend-Profitability Relationship: Model 4 Dependent (Regressed) Variable: $\triangle$ ROA2ABS\%; Independent Variable (Regressor): $\Delta$ Cash Dividend\%

PANEL A. FINANCIAL COMPANIES (FFs)

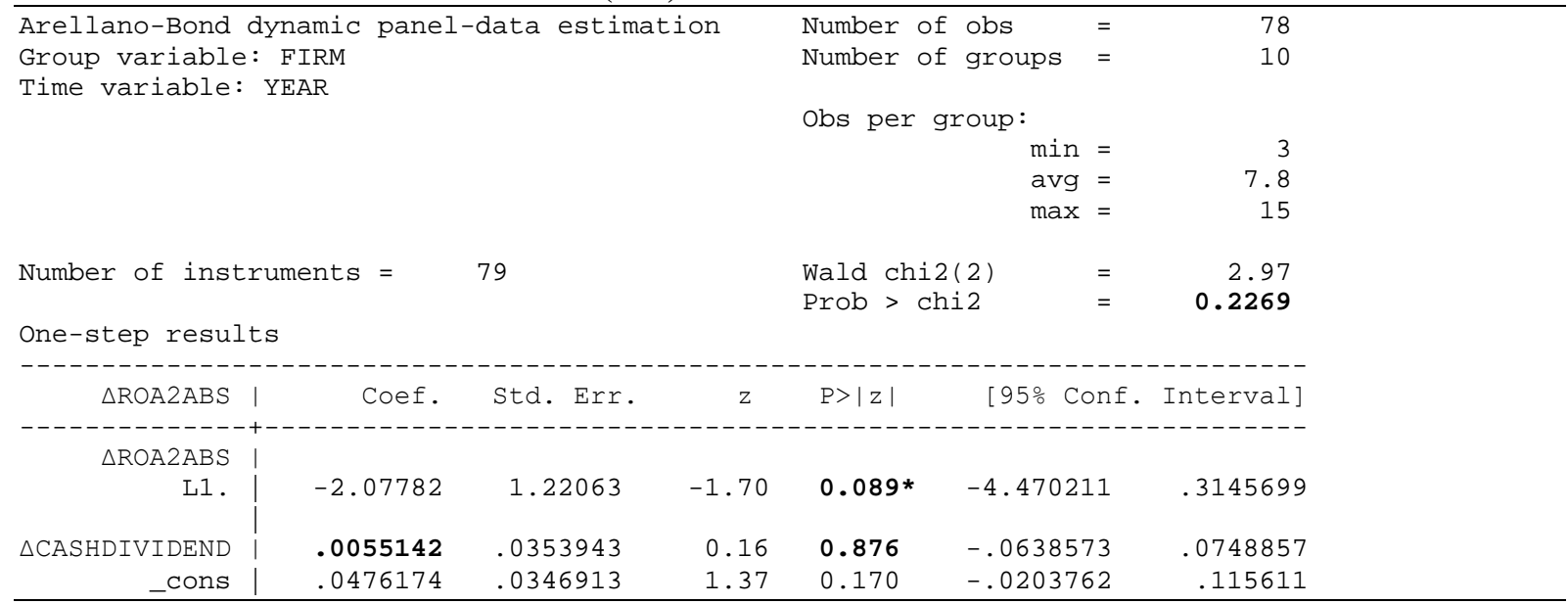




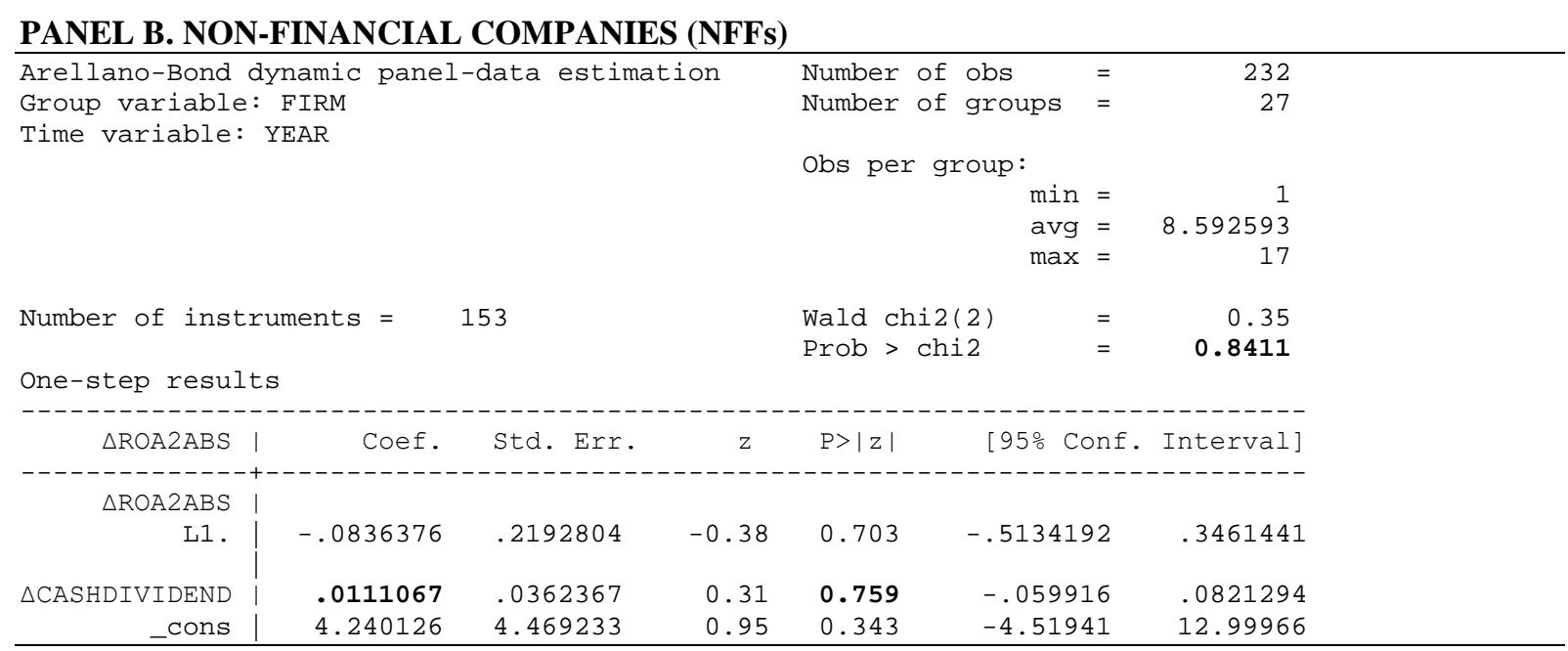

Table 6 above shows the relationship between dividends and corporate profitability (financial performance) where the dependent being the regressed factor is the absolute difference values of the percentages in return on assets being $\triangle \mathrm{ROA} 2 \mathrm{ABS}$. Operating profit is in the numerator in the formula. This can be considered as Model 4. In particular, Panel A and Panel B show the linkage of cash dividends with profitability for FFs and NFFs respectively. In Panel A, the correlation coefficient of $\triangle$ CASHDIDIVEND (.0055142) and $p$ value $(87.6 \%)$ both being marked in bold suggest that there is a positive (the higher [the lower] the dividends the higher [the lower] the profitability), but insignificant relationship between dividend distribution and profitability. Panel A shows that the linkage between lagged $(\triangle \mathrm{ROA} 2 \mathrm{ABSL1})$ and lead $(\triangle \mathrm{ROA} 2 \mathrm{ABS})$ values of the dependent variable being corporate profitability, as given by the p value being $8.9 \%$, is weakly significant. However, the overall model in Panel A does not significantly document any relationship between dividends and profitability either since p value (22.69\%), as marked in bold, greatly exceeds even $10 \%$ (90\% confidence interval). Similarly, Panel B does not document a robust model either where $\mathrm{p}$ value (84.11\%), as marked in bold also, is way higher than $10 \%$ and thus proves to be insignificant at $10 \%$. It also documents that dividend distribution positively relates to profitability where the correlation coefficient is .0111067. However, the p value there being 75.9\% is insignificant there. Therefore, neither in FFs nor in NFFs, cash dividends do not account for the changes in the profitability being financial performance.

Table 7 below documents the relationship between dividends and corporate profitability (financial performance) where the dependent being the regressed factor is the percentage change in return on capital being $\triangle \mathrm{ROC} 1$. Earnings before tax is in the numerator in the formula. This can be considered as Model 5. In particular, Panel A and Panel B show the linkage of cash dividends with profitability for FFs and NFFs respectively. In Panel A, the correlation coefficient of $\triangle$ CASHDIDIVEND (.0063093) and $p$ value $(97.2 \%)$ both being marked in bold suggest that there is a positive (the higher [the lower] the dividends the higher [the lower] the profitability), but insignificant relationship between dividend distribution and profitability. The overall model in Panel A however does significantly show the relationship between dividends and profitability since p value (6.73\%), as marked in bold, falls short of $10 \%$. In other words, it is significant at $90 \%$ confidence interval. In addition, Panel A shows that the linkage between lagged $(\triangle \mathrm{ROC} 1 \mathrm{~L} 1)$ and lead $(\triangle \mathrm{ROC} 1)$ values of the dependent 
variable being corporate profitability, as given by the $\mathrm{p}$ value being $2 \%$, is significant. Similarly, Panel B also documents a very robust model where $\mathrm{p}$ value $(0.56 \%)$, as marked in bold also, is even lower than $1 \%$ and thus proves to be significant at $1 \%$. Panel B provides that the linkage between lagged $(\triangle \mathrm{ROC} 1 \mathrm{~L} 1)$ and lead $(\triangle \mathrm{ROC} 1)$ values of the dependent variable being corporate profitability, as given by the $\mathrm{p}$ value being $0.1 \%$, is very significant. It also documents that dividend distribution is negatively linked to profitability where the correlation coefficient is -.0018944. However, the p value there being $92.2 \%$ is insignificant there. Therefore, neither in FFs nor in NFFs, cash dividends do not account for the changes in the profitability being financial performance.

Table 7. Dividend-Profitability Relationship: Model 5

Dependent (Regressed) Variable: $\triangle$ ROC1\%;

Independent Variable (Regressor): $\Delta$ Cash Dividend\%

PANEL A. FINANCIAL COMPANIES (FFs)

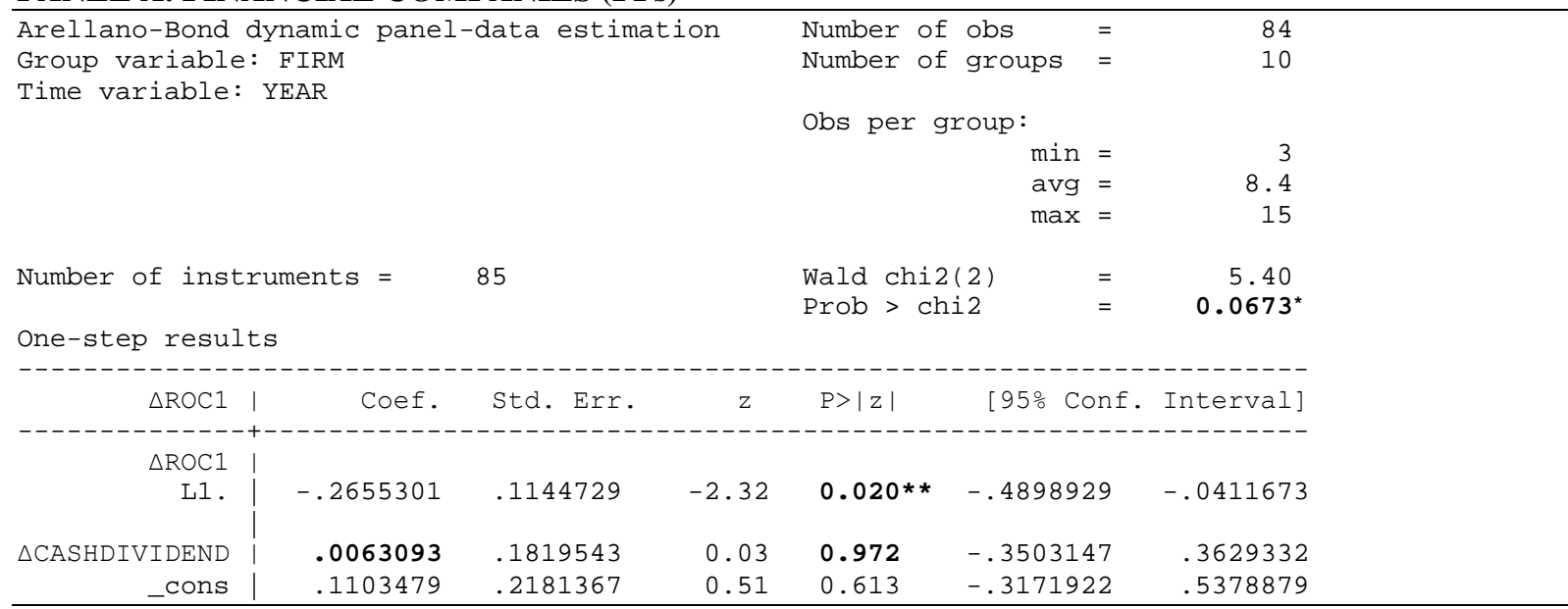

PANEL B. NON-FINANCIAL COMPANIES (NFFs)

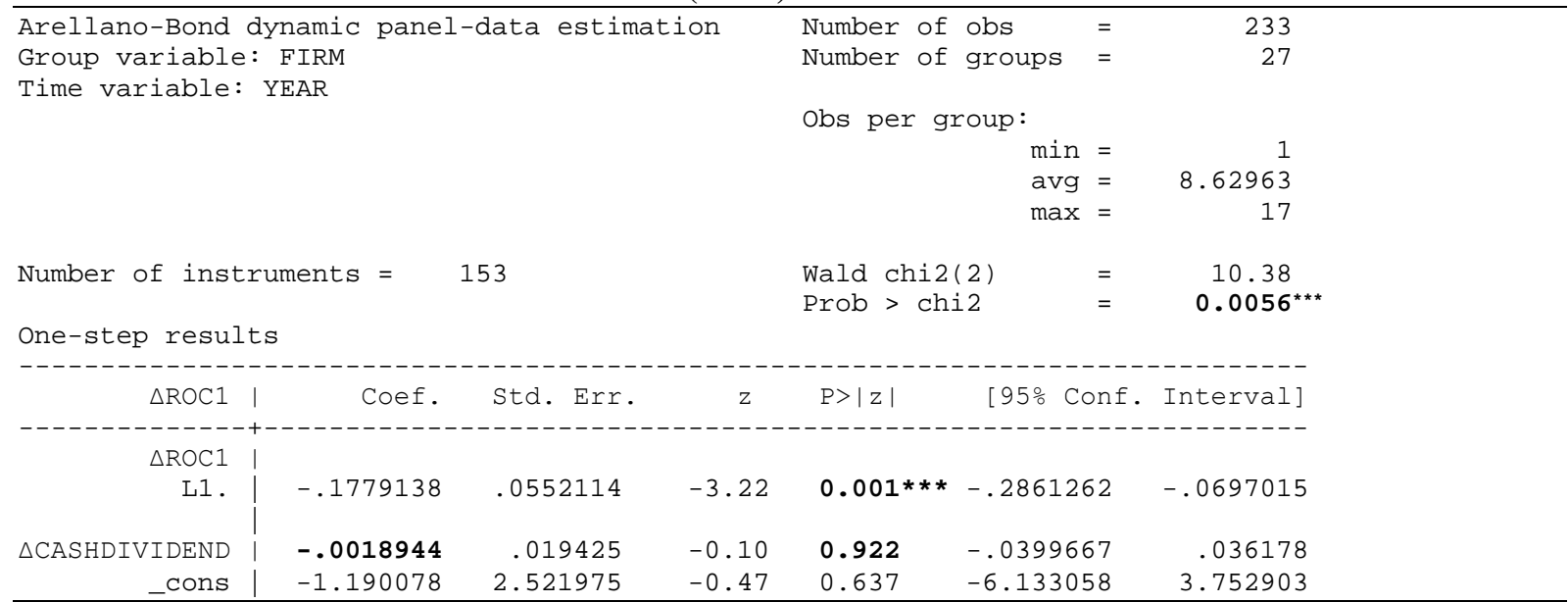


Table 8. Dividend-Profitability Relationship: Model 6

Dependent (Regressed) Variable: $\triangle$ ROC1ABS\%;

Independent Variable (Regressor): $\Delta$ Cash Dividend\%

\section{PANEL A. FINANCIAL COMPANIES (FFs)}

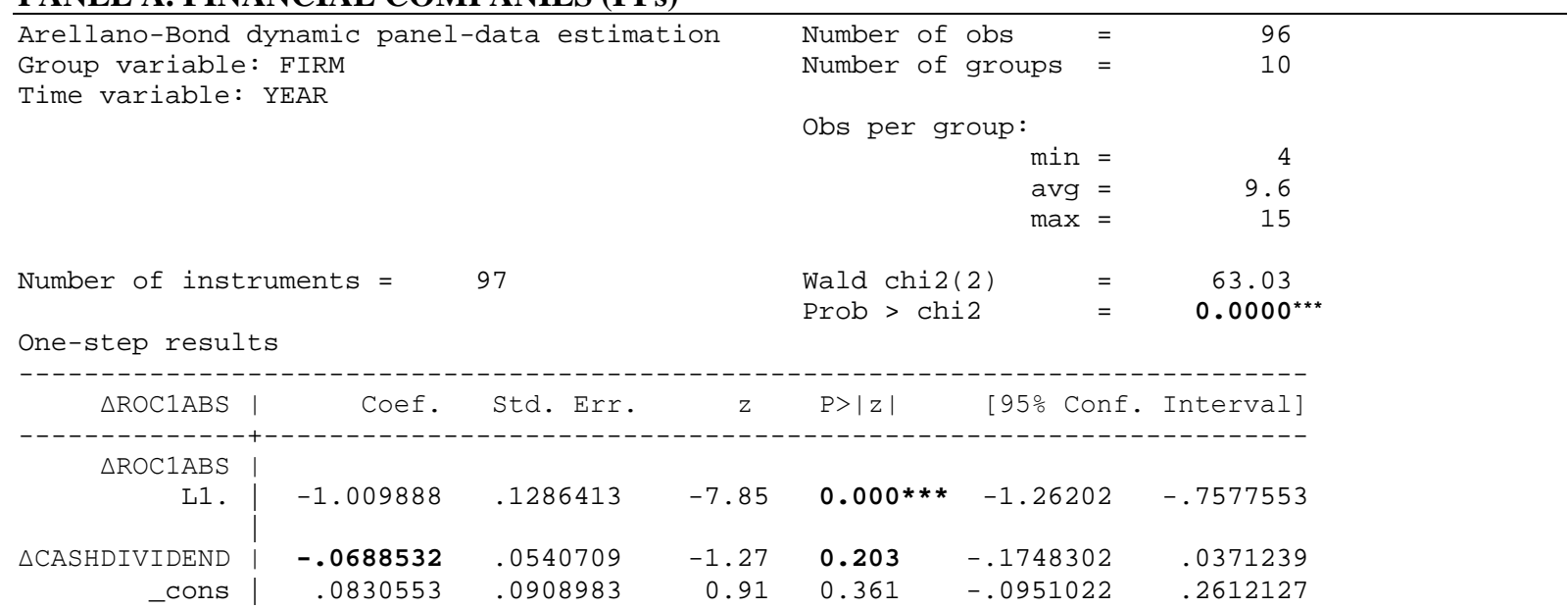

PANEL B. NON-FINANCIAL COMPANIES (NFFs)

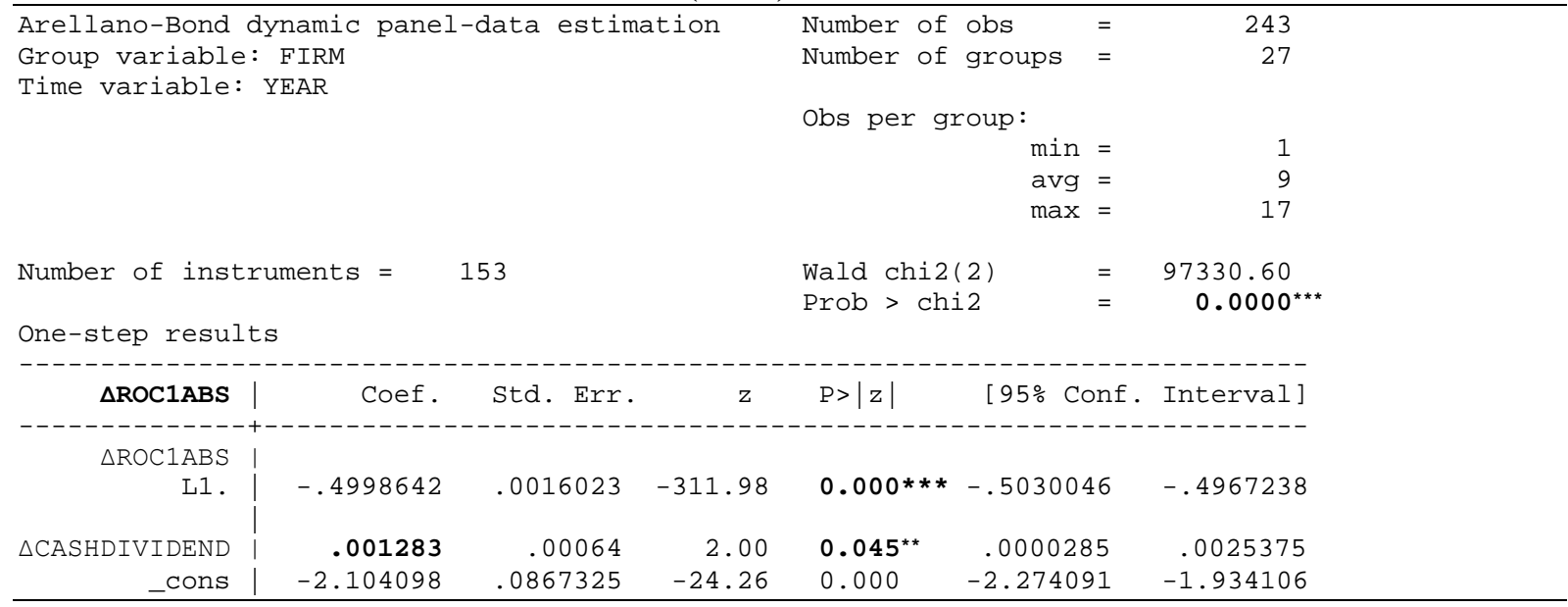

Table 8 above shows the relationship between dividends and corporate profitability (financial performance) where the dependent being the regressed factor is the absolute difference values of the percentages in return on capital being $\triangle$ ROC1ABS. Earnings before tax is in the numerator in the formula. This can be considered as Model 6. In particular, Panel A and Panel B show the linkage of cash dividends with profitability for FFs and NFFs respectively. In Panel A, the correlation coefficient of $\triangle$ CASHDIDIVEND (-0.0688532) and p value (20.3\%) both being marked in bold suggest that there is a negative but insignificant relationship between dividend distribution and profitability. The overall model in Panel A however does show the existence of significant relationship between dividends and profitability since $\mathrm{p}$ value $(0.00 \%)$, as marked in bold, even much less than $1 \%$. In other words, it is significant at $99 \%$ confidence interval. Panel A also indicates that the linkage between lagged $(\triangle \mathrm{ROC} 1 \mathrm{ABSL} 1)$ and lead $(\triangle \mathrm{ROC} 1 \mathrm{ABS})$ values of the dependent variable being corporate profitability, as given by the $\mathrm{p}$ value being $0.00 \%$, is very significant. Similarly, Panel B documents a very robust model where p value $(0.00 \%)$, as marked in bold 
also, is also even lower than $1 \%$ and thus proves to be significant at $1 \%$. It also points that dividend distribution positively relates to profitability where the correlation coefficient is 0.001283 while showing that the linkage between lagged ( $\triangle$ ROC1ABSL1) and lead $(\triangle \mathrm{ROC} 1 \mathrm{ABS})$ values of the dependent variable being corporate profitability, as given by the $\mathrm{p}$ value being $0.00 \%$, is very significant. In addition, the $\mathrm{p}$ value there being $4.5 \%$ is significant there. Therefore, unlike in the case of FFs, cash dividends do account for the changes in the profitability being financial performance in the case of NFFs.

Table 9 below documents the relationship between dividends and corporate profitability (financial performance) where the dependent being the regressed factor is the percentage change in return on capital being $\triangle \mathrm{ROC} 2$. Earnings before tax is in the numerator in the formula. This can be considered as Model 7. In particular, Panel A and Panel B show the linkage of cash dividends with profitability for FFs and NFFs respectively. In Panel A, the correlation coefficient of $\triangle$ CASHDIDIVEND (0.3545754) and $p$ value (89.2\%) both being marked in bold suggest that there is a positive (the higher [the lower] the dividends the higher [the lower] the profitability), but insignificant relationship between dividend distribution and profitability. The overall model in Panel A however does significantly show the relationship between dividends and profitability since p value $(0.73 \%)$, as marked in bold, comes less than $1 \%$. In other words, it is very significant at $99 \%$ confidence interval. Panel A also indicates that the linkage between lagged $(\triangle \mathrm{ROC} 2 \mathrm{~L} 1)$ and lead $(\triangle \mathrm{ROC} 2)$ values of the dependent variable being corporate profitability, as given by the $\mathrm{p}$ value being $0.2 \%$, is very significant. On the contrary, Panel B documents a non-robust model where p value (85.04\%), as marked in bold also, is much higher than $10 \%$ and thus proves to be insignificant even at $10 \%$. It also documents that dividend distribution is negatively linked to profitability where the correlation coefficient is -0.3192734 . However, the $\mathrm{p}$ value there being $64.9 \%$ is insignificant there. Therefore, neither in FFs nor in NFFs, cash dividends do not account for the changes in the profitability being financial performance.

\section{Table 9. Dividend-Profitability Relationship: Model 7 Dependent (Regressed) Variable: $\triangle \mathrm{ROC} \%$; Independent Variable (Regressor): $\Delta$ Cash Dividend $\%$}

PANEL A. FINANCIAL COMPANIES (FFs)

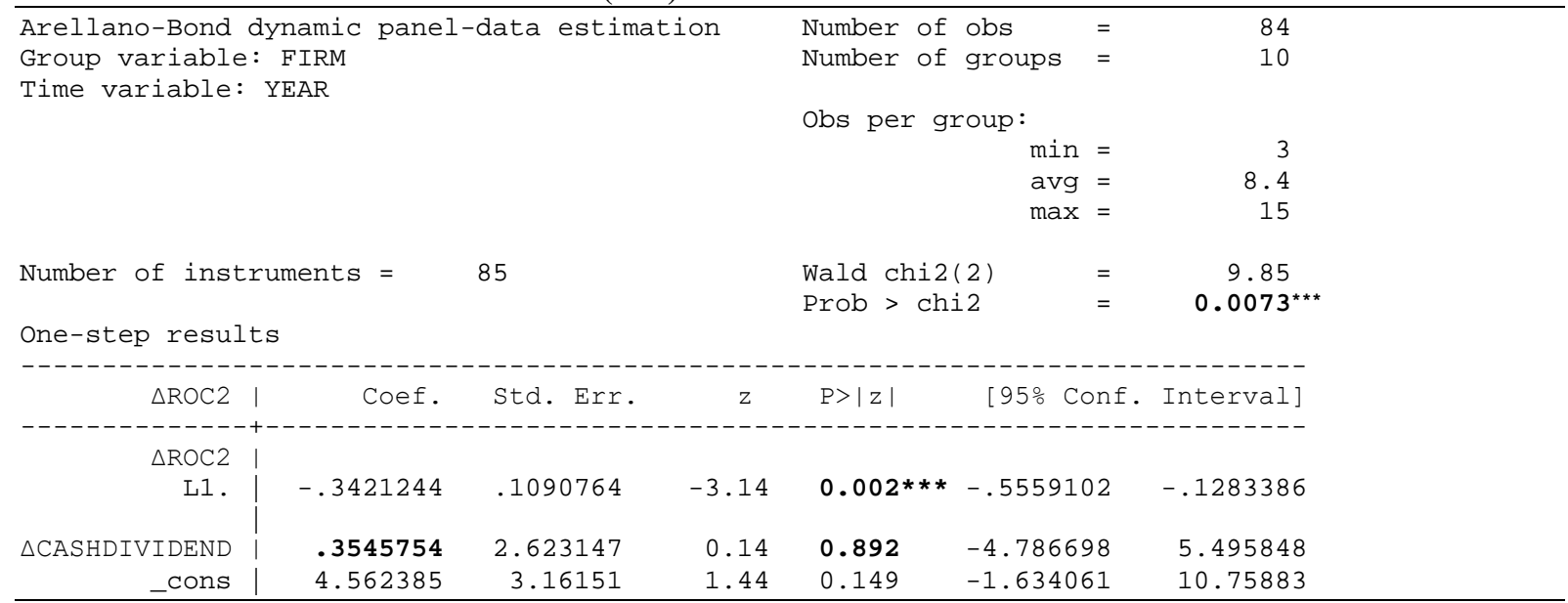




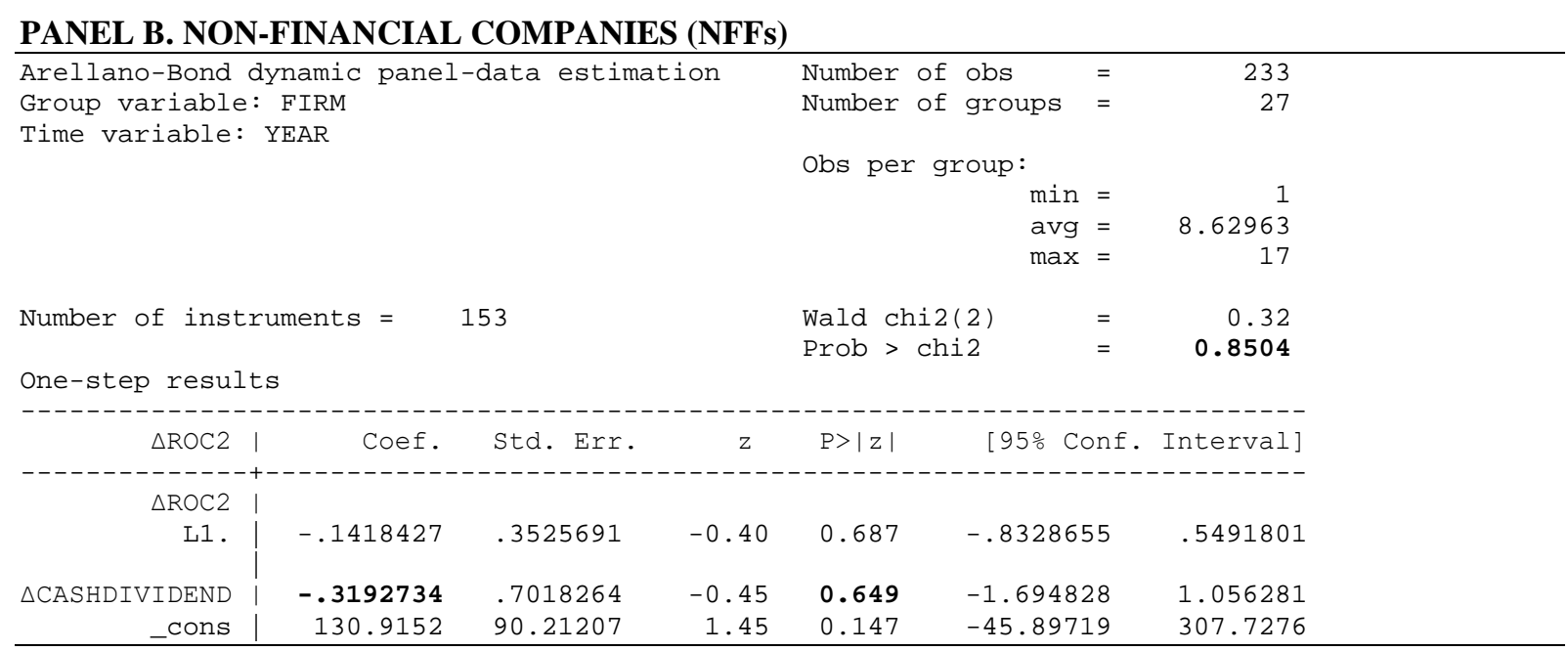

Table 10 below documents the relationship between dividends and corporate profitability (financial performance) where the dependent being the regressed factor is the absolute difference values of the percentages in return on capital being $\triangle$ ROC2ABS. Operating profit is in the numerator in the formula. This can be considered as Model 8. In particular, Panel A and Panel B show the linkage of cash dividends with profitability for FFs and NFFs respectively. In Panel A, the correlation coefficient of $\triangle$ CASHDIDIVEND (0.2122503 ) and p value (51.5\%) both being marked in bold suggest that there is a negative but insignificant relationship between dividend distribution and profitability. The overall model in Panel A however does show the existence of significant relationship between dividends and profitability since $\mathrm{p}$ value $(0.00 \%)$, as marked in bold, even much less than $1 \%$. In other words, it is significant at $99 \%$ confidence interval. Panel A also provides that the linkage between lagged $(\triangle \mathrm{ROC} 2 \mathrm{ABSL} 1)$ and lead $(\triangle \mathrm{ROC} 2 \mathrm{ABS})$ values of the dependent variable being corporate profitability, as given by the $p$ value being $0.00 \%$, is very significant. On the other hand, Panel B does not document a robust model where p value (96.81\%), as marked in bold also, is also much higher than $10 \%$ and thus proves to be too insignificant. It also documents that dividend distribution positively relates to profitability where the correlation coefficient is 0.1440004 . However, the p value there being $81.7 \%$ is too insignificant there also. Therefore, neither in the case of FFs nor NFFs, cash dividends account for the changes in the profitability being financial performance in the case of NFFs at all.

Table 10. Dividend-Profitability Relationship: Model 8

Dependent (Regressed) Variable: $\triangle$ ROC2ABS\%;

Independent Variable (Regressor): $\Delta$ Cash Dividend\%

PANEL A. FINANCIAL COMPANIES (FFs)

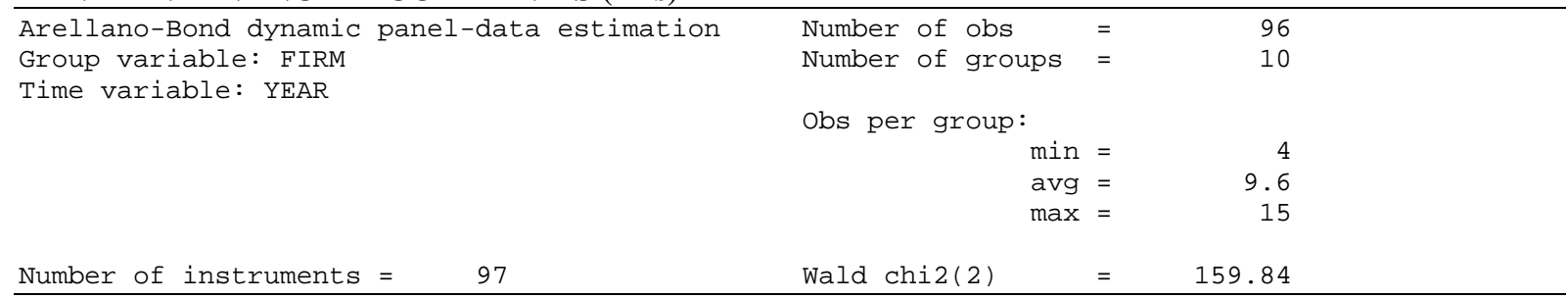




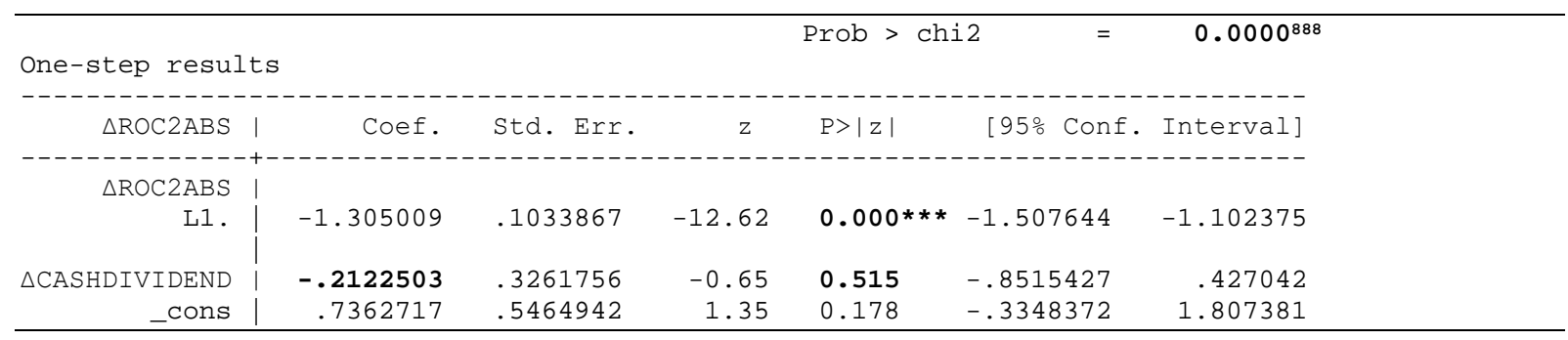

\section{PANEL B. NON-FINANCIAL COMPANIES (NFFs)}

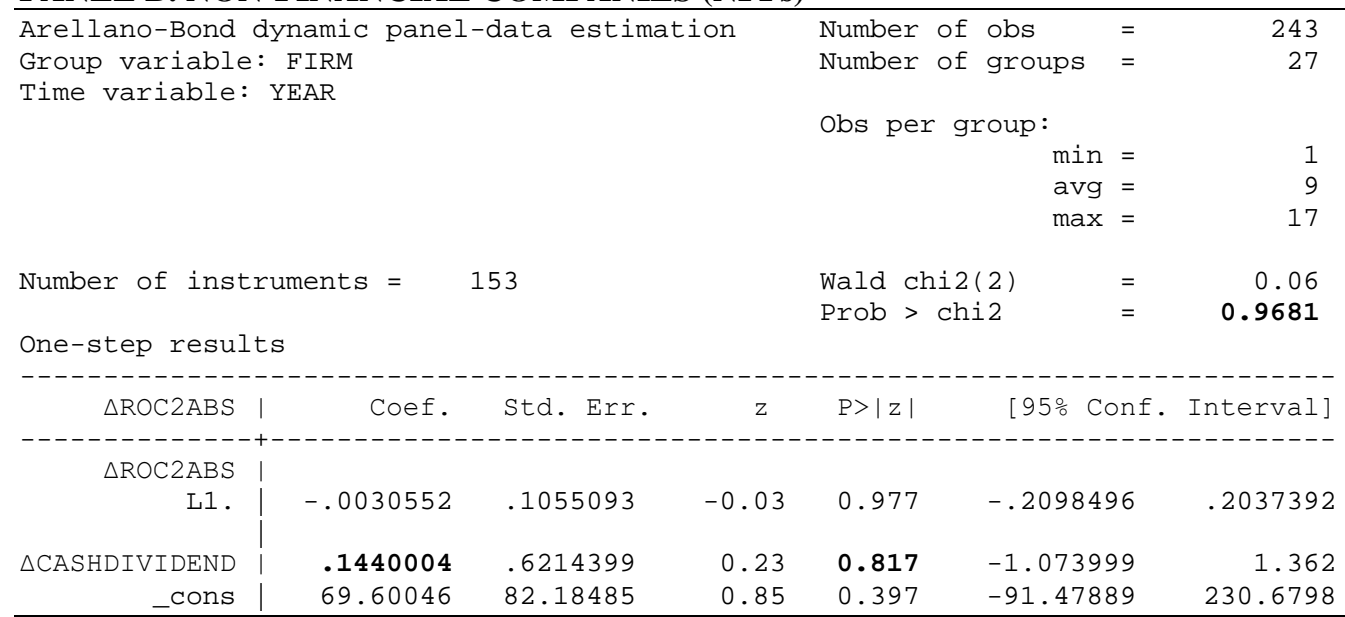

Table 11. Dividend-Profitability Relationship: Model 9

Dependent (Regressed) Variable: $\Delta \mathrm{OP} \%$;

Independent Variable (Regressor): $\Delta$ Cash Dividend\%

PANEL A. FINANCIAL COMPANIES (FFs)

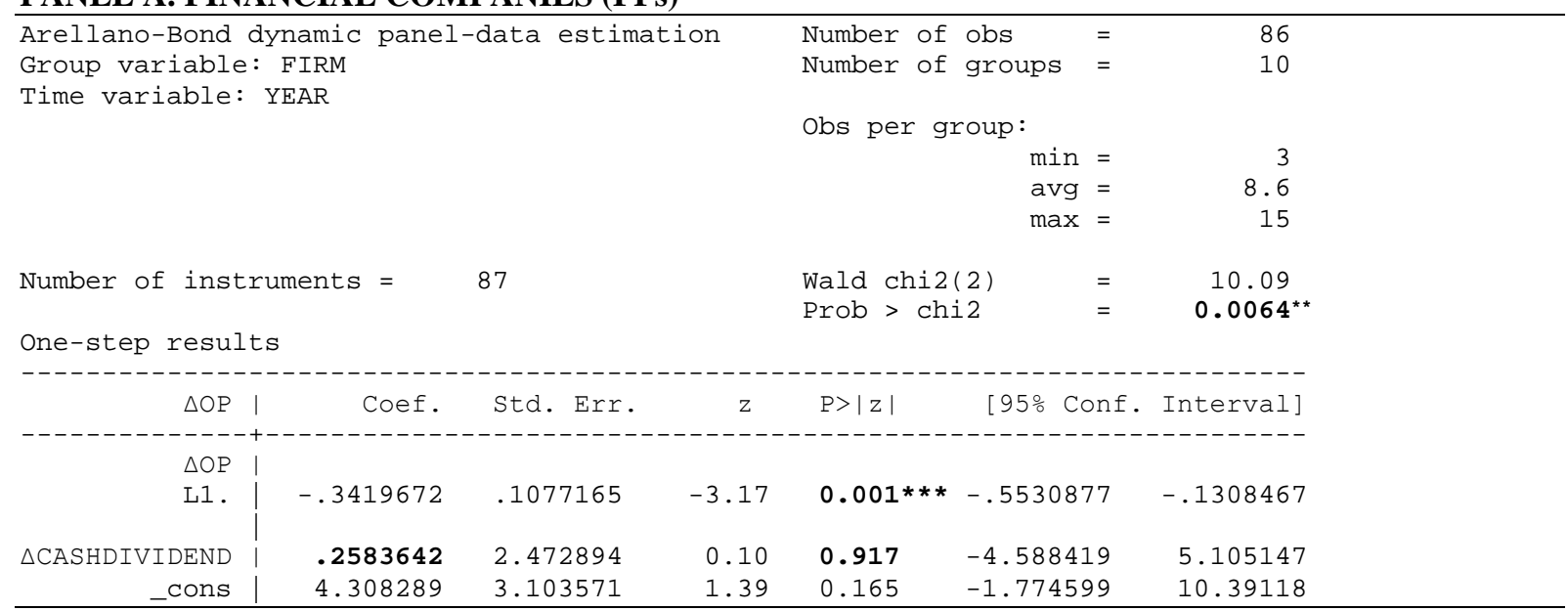




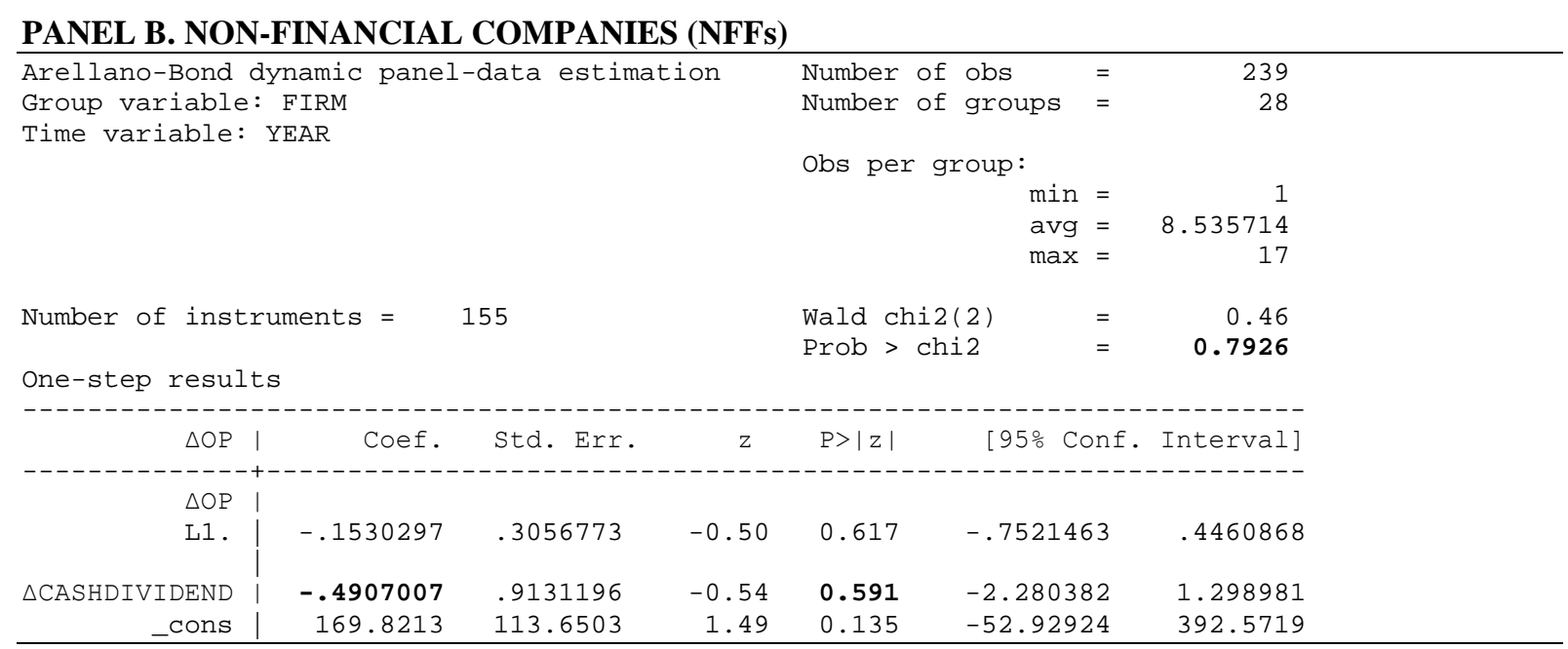

Table 11 above displays the relationship between dividends and corporate profitability (financial performance) where the dependent being the regressed factor is the percentage change in operating profit being $\Delta \mathrm{OP}$. This can be considered as Model 9. In particular, Panel $A$ and Panel B show the linkage of cash dividends with profitability for FFs and NFFs respectively. In Panel A, the correlation coefficient of $\triangle$ CASHDIDIVEND (0.2583642) and $p$ value $(91.7 \%)$ both being marked in bold suggest that there is a positive (the higher [the lower] the dividends the higher [the lower] the profitability), but insignificant relationship between dividend distribution and profitability. The overall model in Panel A however does significantly show the relationship between dividends and profitability since p value $(0.64 \%)$, as marked in bold, comes less than $1 \%$. In other words, it is very significant at $99 \%$ confidence interval. Panel $\mathrm{A}$ also indicates that the linkage between lagged ( $\triangle$ OPL1) and lead $(\triangle \mathrm{OP})$ values of the dependent variable being corporate profitability, as given by the $\mathrm{p}$ value being $0.1 \%$, is very significant. Panel $\mathrm{B}$, unlike Panel $\mathrm{A}$, documents a non-robust model where $\mathrm{p}$ value (79.26\%), as marked in bold also, is much more than $10 \%$ and thus proves to be too insignificant. It also shows that dividend distribution negatively relates to profitability where the correlation coefficient is -0.4907007 . However, the p value there being $59.1 \%$ is insignificant there. Therefore, neither in FFs nor in NFFs, cash dividends do not account for the changes in the profitability being financial performance.

Table 12 below shows the relationship between dividends and corporate profitability (financial performance) where the dependent being the regressed factor is the percentage change in earnings before tax being $\triangle \mathrm{EBT}$. This can be considered as Model 10. In particular, Panel A and Panel B show the linkage of cash dividends with profitability for FFs and NFFs respectively. In Panel A, the correlation coefficient of $\triangle$ CASHDIDIVEND (-0.0530681) and $\mathrm{p}$ value (75.2\%) both being marked in bold suggest that there is a negative and insignificant relationship between dividend distribution and profitability. The overall model in Panel A however does show that there is a significant (not very significant though) relationship between dividends and profitability since p value (5.41\%), as marked in bold, comes less than $10 \%$. In other words, it is significant at $90 \%$ confidence interval. Panel A also provides that the linkage between lagged $(\triangle \mathrm{EBTL1})$ and lead $(\triangle \mathrm{EBT})$ values of the dependent variable being corporate profitability, as given by the $\mathrm{p}$ value being $1.8 \%$, is significant. Panel $\mathrm{B}$, unlike Panel A, documents a very robust model where p value $(0.02 \%)$, as marked in bold 
also, is much lower even than $1 \%$ and thus proves to be very significant. It also shows that dividend distribution is positively linked to profitability where the correlation coefficient is 0.0036176. In parallel to Panel A, Panel B also documents that the linkage between lagged $(\triangle \mathrm{EBTL1})$ and lead $(\triangle \mathrm{EBT})$ values of the dependent variable being corporate profitability, as given by the p value being $0.00 \%$, is (very) significant. However, the p value there being 84.5\% is insignificant there. Therefore, neither in FFs nor in NFFs, cash dividends do not account for the changes in the profitability being financial performance.

Table 12. Dividend-Profitability Relatiinship: Model 10

Dependent (Regressed) Variable: $\triangle \mathrm{EBT} \%$;

Independent Variable (Regressor): $\Delta$ Cash Dividend\%

PANEL A. FINANCIAL COMPANIES (FFs)

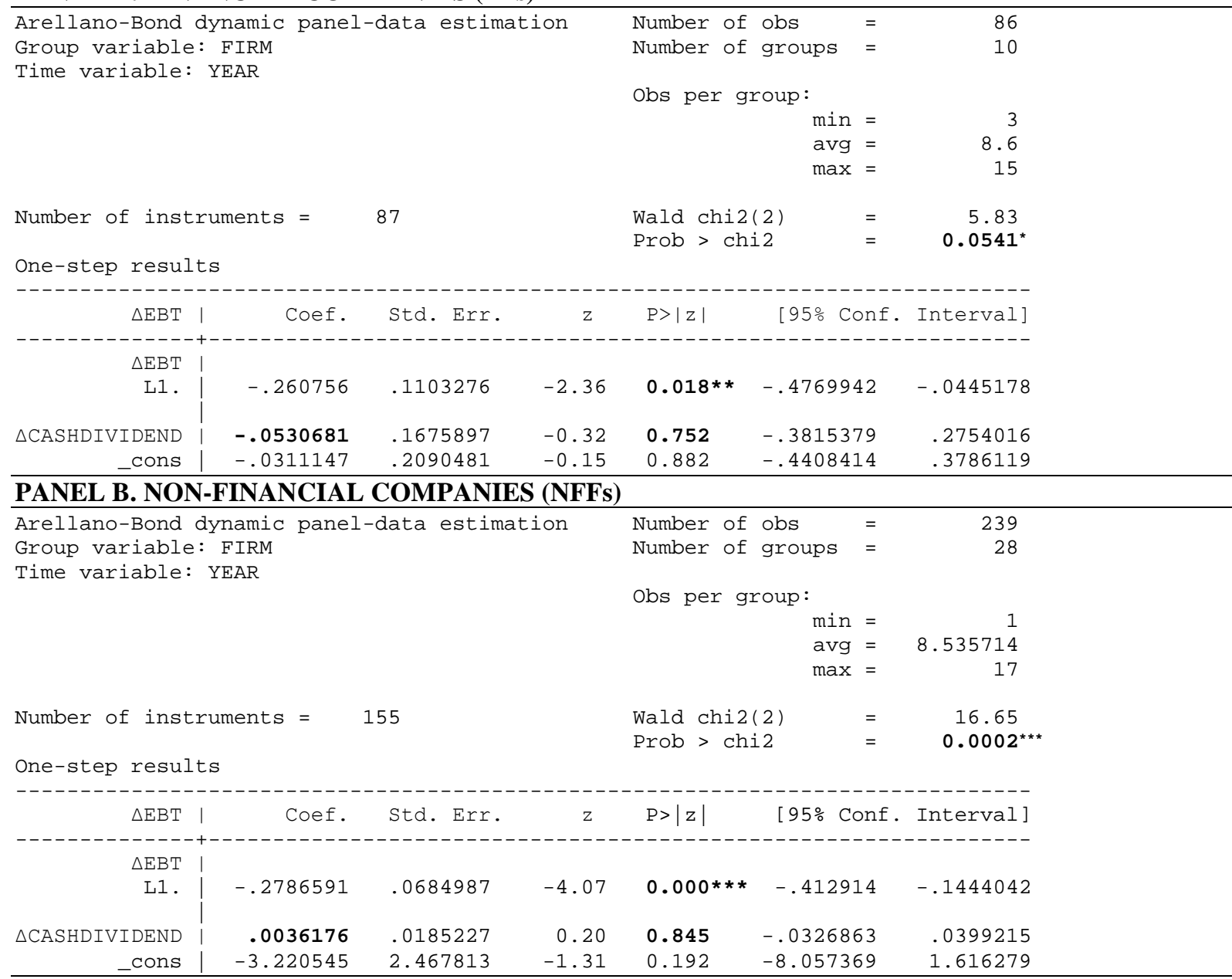

Table 13. Dividend-Profitability Relationship: Model 11

Dependent (Regressed) Variable: $\triangle \mathrm{EPS} \%$;

Independent Variable (Regressor): $\Delta$ Cash Dividend\%

PANEL A. FINANCIAL COMPANIES (FFs)

\begin{tabular}{lll}
\hline Arellano-Bond dynamic panel-data estimation & Number of obs $=$ & 61 \\
Group variable: FIRM & Number of groups $=$ & 10 \\
Time variable: YEAR & Obs per group: & \\
& & \\
\hline
\end{tabular}




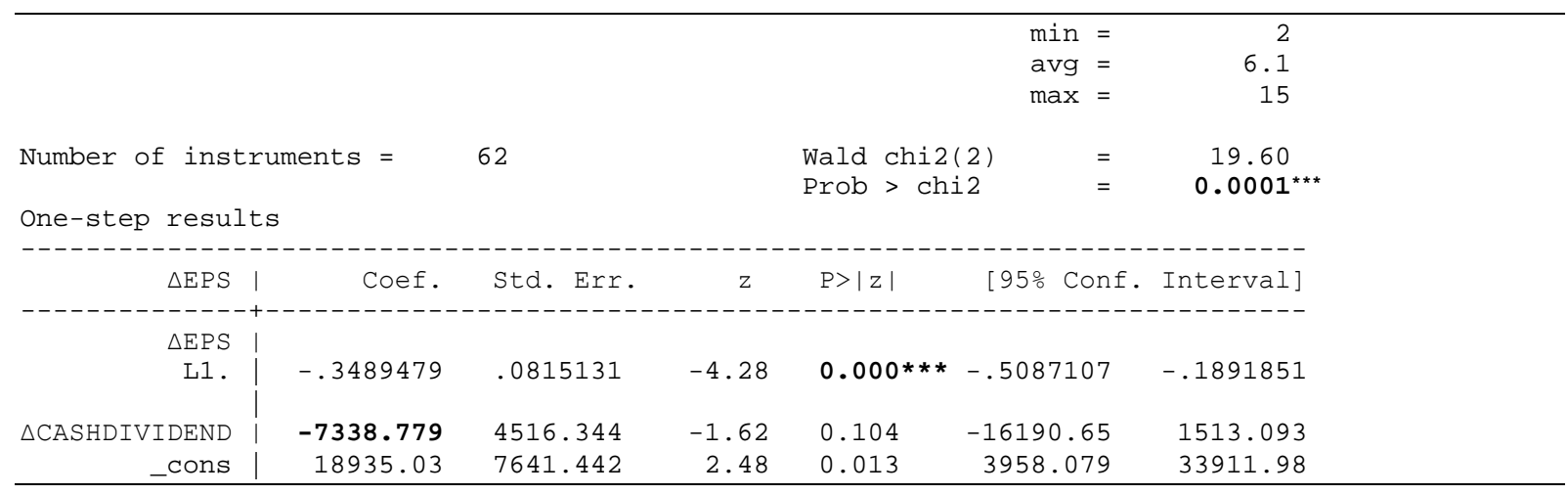

PANEL B. NON-FINANCIAL COMPANIES (NFFs)

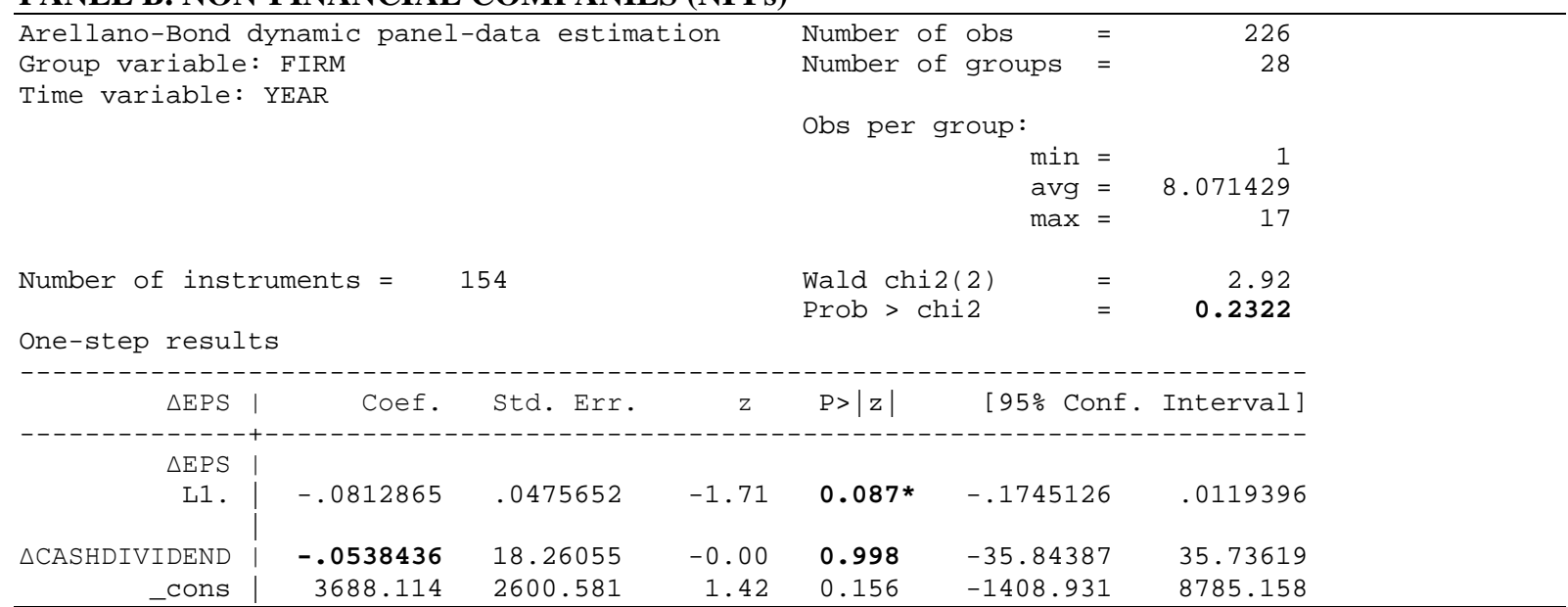

Table 13 above shows the relationship between dividends and corporate profitability (financial performance) where the dependent being the regressed factor is the percentage change in earnings per share being $\triangle \mathrm{EPS}$. This can be considered as Model 11. In particular, Panel A and Panel B show the linkage of cash dividends with profitability for FFs and NFFs respectively. In Panel A, the correlation coefficient of $\triangle$ CASHDIDIVEND (-7338.779) and $p$ value (10.4\%) both being marked in bold suggest that there is a negative and insignificant (almost significant at 10\%) relationship between dividend distribution and profitability. The overall model in Panel A however does show that there is a very significant relationship between dividends and profitability since p value (0.01\%), as marked in bold, converges at 0 meaning significant at $1 \%$. Panel $\mathrm{A}$ further shows that the linkage between lagged ( $\triangle \mathrm{EPSL} 1$ ) and lead ( $\triangle \mathrm{EPS}$ ) values of the dependent variable being corporate profitability, as given by the p value being $0.00 \%$, is very significant. Panel $\mathrm{B}$, unlike Panel A, documents a non-robust model where p value (23.22\%), as marked in bold also, is higher than $10 \%$ and thus proves to be too insignificant. Panel $B$ shows that the linkage between lagged ( $\triangle$ EPSL1) and lead ( $\triangle$ EPS) values of the dependent variable being corporate profitability, as given by the $p$ value being $8.7 \%$, is poorly significant. It also documents that dividend distribution negatively relates to profitability where the correlation coefficient is -0.0538436 . However, the p value there being $99.8 \%$ is too insignificant there. Therefore, neither in FFs nor in NFFs, cash dividends do not account for the changes in the profitability being financial performance. 
Table 14 below shows the relationship between dividends and corporate profitability (financial performance) where the dependent being the regressed factor is the absolute difference values of the percentages in earnings per share being $\triangle E P S A B S$. This can be considered as Model 12. In particular, Panel A and Panel B show the linkage of cash dividends with profitability for FFs and NFFs respectively. In Panel A, the correlation coefficient of $\triangle$ CASHDIDIVEND (-1.375395) and p value (68.5\%) both being marked in bold suggest that there is a negative and insignificant relationship between dividend distribution and profitability. The overall model in Panel A also suggests that there is no significant relationship between dividends and profitability since p value (38.69\%), as marked in bold, is even a lot more than $10 \%$. Panel B, unlike Panel A, documents a very robust model where $\mathrm{p}$ value $(0.00 \%)$, as marked in bold also, is much lower even than $1 \%$ and thus proves to be very significant. It provides that the linkage between lagged ( $\triangle$ EPSABSL1) and lead ( $\triangle$ EPSABS $)$ values of the dependent variable being corporate profitability, as given by the $p$ value being $0.00 \%$, is very significant, unlike in Panel A. It also shows that dividend distribution is positively correlated to profitability where the correlation coefficient is 0.0004117. However, the $\mathrm{p}$ value there being $96.9 \%$ is too insignificant there. Therefore, neither in FFs nor in NFFs, cash dividends do not account for the changes in the profitability being financial performance.

Table 14. Dividend-Profitability Relationship: Model 12

Dependent (Regressed) Variable: $\triangle$ EPSABS\%;

Independent Variable (Regressor): $\triangle$ Cash Dividend\%

PANEL A. FINANCIAL COMPANIES (FFs)

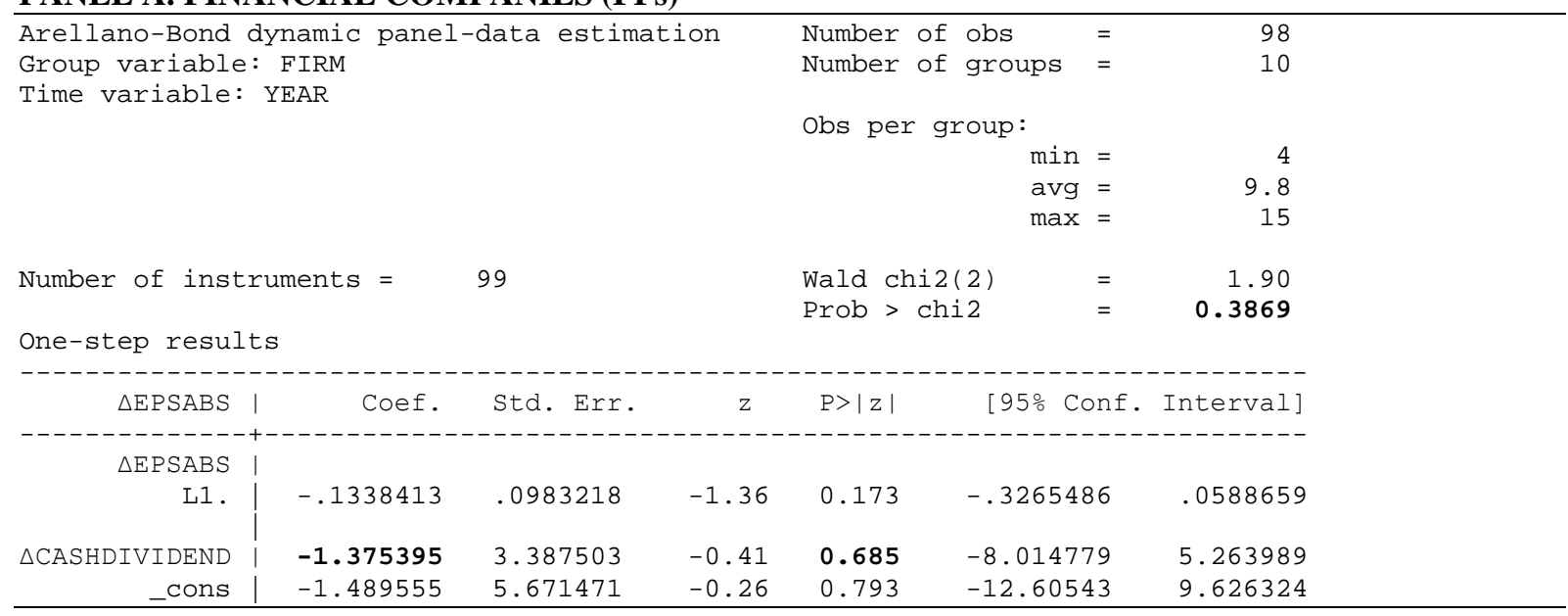

PANEL B. NON-FINANCIAL COMPANIES (NFFs)

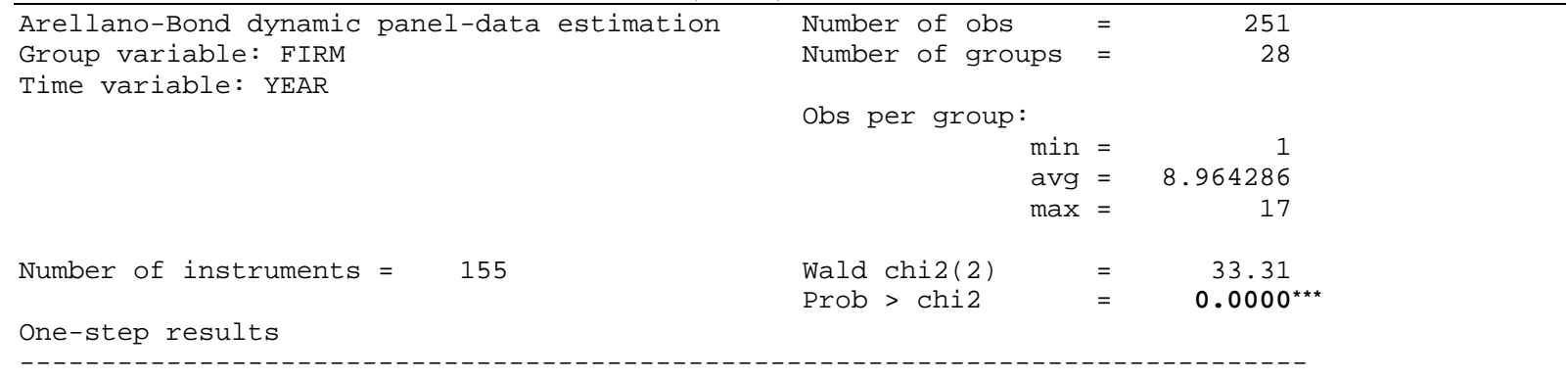




\begin{tabular}{|c|c|c|c|c|c|c|}
\hline$\triangle \mathrm{EPSABS}$ & Coef. & Std. Err. & $z$ & $\mathrm{P}>|\mathrm{z}|$ & [95\% Conf. & Interval] \\
\hline \multicolumn{7}{|c|}{ 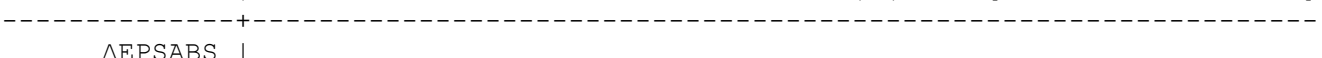 } \\
\hline $\begin{array}{r}\triangle \mathrm{EPSABS} \\
\mathrm{L} 1 .\end{array}$ & -.3604154 & .0624503 & -5.77 & $0.000 * * *$ & -.4828157 & -.2380152 \\
\hline$\triangle$ CASHDIVIDEND & .0004117 & .0106209 & 0.04 & 0.969 & -.0204048 & .0212281 \\
\hline _cons & - . . 0127426 & 1.363534 & -0.01 & 0.993 & -2.68522 & 2.659735 \\
\hline
\end{tabular}

The next section concludes this paper with some remarks.

\section{CONCLUSION}

Dividends (profit share) and profitability (financial performance) remain unarguably among the most salient attributes of financial research. Several financial theories were developed to explain the interrelationship between these two important accounting narratives. This paper was interested in exploring if and how signalization theory works in general while being interested in also exploring to what extent dividends may account for the corporate profitability being corporate financial performance in particular. Two hypotheses were mainly constructed and tested to achieve this objective.

Following a post-selection, our sample included top 45 companies that are listed in Borsa Istanbul, the main and only stock exchange in Turkey that is an emerging market. The sampling time window spanned the period from 2000 through 2018. In order to control for any group differences within our sample distribution, listed companies were decomposed into financial (FFs) and non-financial companies (NFFs) so that the predicted relationships could have possibly been analyzed individually and been compared together. To capture dynamic possible nature of dividend (profitability determinant)-and-profitability linkage by definition, dynamic panel analysis was performed to test our predictions and to best capture the group comparison along with temporal (time series) and cross-sectional (firms) dimensions concomitantly.

Cash dividends listed companies paid out is considered as an explanatory variable in the analyses. In an attempt to ensure an acceptable level of robustness, a broad mix (twelve) of dependent (regressed) variables that are regressed on cash dividend is considered to capture corporate profitability. In particular, independent variable as a proxy to indicate dividends was given to be percentage change in cash dividend paid out. Dependent variables as proxies to indicate corporate profitability or financial performance were given as percentage change in Return on Assets (Four [4] different versions developed and tested), percentage change in Return on Capital (Four [4] different versions developed and tested), percentage change in Operating Profit, percentage change in Earnings Before Tax, percentage change in Earnings Per Share (Two [2] different versions developed and tested). Since one independent factor alone was used for all twelve dependent factors each exclusively, twelve (12) models were analyzed in this paper.

In particular, Model 1 where the dependent variable being proxied as $\triangle \mathrm{ROA} 1$ which was defined to be \% Change in Return on Assets (= \% Change in Earnings Before Tax/Total Assets) was found to be significant (significant at 5\%) for NFFs but insignificant for FFs. There, neither in FFs nor in NFFs, cash dividends do not account for the changes in the profitability being financial performance. In other words, dividends were documented to be 
irrelevant in explaining future corporate profitability. In Model 2, the dependent variable was proxied as $\triangle \mathrm{ROA} 1 \mathrm{ABS}$ which was defined to be the absolute difference (change) values of the percentages (\%) in return on assets (Earnings Before Tax/Total Assets). The overall model was found to be very significant (significant at 1\%) for NFFs (attributable to the strong [significant] linkage between the lagged and the lead values of the dependent variable being corporate profitability or corporate financial performance) but insignificant for FFs. There, neither in FFs nor in NFFs, cash dividends do not account for the changes in the profitability being financial performance. In other words, dividends were documented to be irrelevant in explaining future corporate profitability also here.

Model 3 where the dependent variable being proxied as $\triangle \mathrm{ROA} 2$ which was defined to be \% Change in Return on Assets (= \% Change in Operating Profit/Total Assets) was found to be insignificant for NFFs and FFs both. In addition, there, neither in FFs nor in NFFs, cash dividends do not account for the changes in the profitability being financial performance. In other words, dividends were documented to be irrelevant in explaining future corporate profitability. In Model 4, the dependent variable was proxied as $\triangle$ ROA2ABS which was defined to be the absolute difference (change) values of the percentages (\%) in return on assets (Operating Profit/Total Assets). The overall model was found to be insignificant both for NFFs and FFs. There, neither in FFs nor in NFFs, cash dividends do not account for the changes in the profitability being financial performance. In other words, dividends were also documented to be irrelevant in explaining future corporate profitability.

In particular, Model 5 where the dependent variable being proxied as $\triangle \mathrm{ROC} 1$ which was defined to be \% Change in Return on Capital (= \% Change in Earnings Before Tax/Paidin Capital) was found to be poorly significant (significant at 10\%) for NFFs but very significant for FFs (attributable to the poor [weak] linkage between the lagged and the lead values of the dependent variable being corporate profitability or corporate financial performance). There, neither in FFs nor in NFFs, cash dividends do not account for the changes in the profitability being financial performance. In other words, dividends were documented to be irrelevant in explaining future corporate profitability. In Model 6, the dependent variable was proxied as $\triangle$ ROC1ABS which was defined to be the absolute difference (change) values of the percentages (\%) in return on capital (Earnings Before Tax/ Paid-in Capital). The overall model was found to be very significant both for NFFs and FFs (attributable to the strong [significant] linkage between the lagged and the lead values of the dependent variable being corporate profitability or corporate financial performance). Unlike the FFs, in NFFs, cash dividends do account for the changes in the profitability. Further, the relationship between present corporate dividend distribution and future corporate profitability is positive, suggesting the higher (lower) the dividends the higher (lower) the profitability. In other words, dividends were documented to be relevant there in explaining future corporate profitability. This is the only model in this paper proving so.

Model 7 where the dependent variable being proxied as $\triangle \mathrm{ROA} 2$ which was defined to be \% Change in Return on Assets (= \% Change in Operating Profit/Paid-in Capital) was found to be very significant for FFs (attributable to the strong [significant] linkage between the lagged and the lead values of the dependent variable being corporate profitability or corporate financial performance) but insignificant for NFFs. In addition, there, neither in FFs nor in NFFs, cash dividends do not account for the changes in the profitability being financial performance. In other words, dividends were documented to be irrelevant in explaining future 
corporate profitability. Likewise; in Model 8, the dependent variable was proxied as $\triangle \mathrm{ROA} 2 \mathrm{ABS}$ which was defined to be the absolute difference (change) values of the percentages (\%) in return on assets (Operating Profit/Paid-in Capital). The overall model was found to be insignificant both for NFFs and FFs. There, neither in FFs nor in NFFs, cash dividends do not account for the changes in the profitability being financial performance. In other words, dividends were also documented to be irrelevant in explaining future corporate profitability.

Model 9 where the dependent variable being proxied as $\Delta \mathrm{OP}$ which was defined to be $\%$ Change in Operating Profit was found to be very significant for FFs (attributable to the strong linkage between the lagged and the lead values of the dependent variable being corporate profitability or corporate financial performance) but insignificant for NFFs. In addition, there, neither in FFs nor in NFFs, cash dividends do not account for the changes in the profitability being financial performance. In other words, dividends were documented to be irrelevant in explaining future corporate profitability. Model 10 where the dependent variable being proxied as $\triangle \mathrm{EBT}$ which was defined to be $\%$ Change in Earnings Before Tax was found to be poorly significant for FFs (attributable to the poor [weak] linkage between the lagged and the lead values of the dependent variable being corporate profitability or corporate financial performance) but very significant for NFFs. In addition, there, neither in FFs nor in NFFs, cash dividends do not account for the changes in the profitability being financial performance. In other words, dividends were documented to be irrelevant in explaining future corporate profitability.

Model 11 where the dependent variable being proxied as $\triangle \mathrm{EPS}$ which was defined to be \% Change in Earnings Per Share (= \% Change in Net Profit After Tax/Number of Shares) was found to be very significant for FFs (attributable to the strong [significant] linkage between the lagged and the lead values of the dependent variable being corporate profitability or corporate financial performance) but insignificant for NFFs. In addition, there, neither in FFs nor in NFFs, cash dividends do not account for the changes in the profitability being financial performance. In other words, while being close to $10 \%$ significance threshold though, dividends were documented to be irrelevant in explaining future corporate profitability. Likewise; in Model 12, the dependent variable was proxied as $\triangle \mathrm{ROA} 2 \mathrm{ABS}$ which was defined to be the absolute difference (change) values of the percentages (\%) in return on assets (Operating Profit/Paid-in Capital). The overall model was found to be insignificant for FFs but very significant for NFFs (attributable to the strong [significant] linkage between the lagged and the lead values of the dependent variable being corporate profitability or corporate financial performance). There, neither in FFs nor in NFFs, cash dividends do not account for the changes in the profitability being financial performance. In other words, dividends were also documented to be irrelevant in explaining future corporate profitability. 


\section{REFERENCES}

Adaoglu, Cahit (2000), "Instability in The Dividend Policy of The Istanbul Stock Exchange (ISE) Corporations: Evidence From an Emerging Market ”, Emerging Markets Review, Vol. 1, Issue 3, pp. 252-270.

Aharony, Joseph - Swary, Itzhak (1980), “Quarterly Dividend And Earnings Announcements And Stockholders’ Returns: An Empirical Analysis ”, The Journal of Finance, Vol. 35, Issue 1, pp. 1-12.

Aivazian, Varouj - Booth, Laurence - Cleary, Sean (2003), "Do Emerging Market Firms Follow Different Dividend Policies From US Firms? ”, Journal of Financial Research, Vol. 26, Issue 3, pp. 371-387.

Ajanthan, Alagathurai (2013), "The Relationship Between Dividend Payout And Firm Profitability: A Study of Listed Hotels And Restaurant Companies in Sri Lanka ”, International Journal of Scientific And Research Publications, Vol. 3, Issue 6, pp. 1-6.

Allen, Franklin - Michaely, Roni (2003), “ Payout Policy ”, In Handbook of The Economics of Finance Vol. 1, pp. 337-429, Elsevier.

Allen, Franklin - Bernardo, Antonio E. - Welch, Ivo (2000), “ A Theory of Dividends Based on Tax Clienteles”, The Journal of Finance, Vol. 55, Issue 6, pp. 2499-2536.

Ambarish, Ramasastry - Kose, John - Williams, Joseph (1987), “ Efficient Signaling With Dividends And Investments ”, The Journal of Finance, Vol. 42, Issue 2, pp. 321-343.

Arellano, Manuel - Bond, Stephen (1991), “ Some Tests of Specification For Panel Data: Monte Carlo Evidence And an Application to Employment Equations ”, The Review of Economic Studies, Vol. 58, Issue 2, pp. 277-297.

Arslan, Ozgur (2008), “ Perceptions of Managers For Dividend Distributions ”, Hacettepe University, Economics and Administrative Sciences Faculty Journal, Vol. 26, Issue 1, pp. 85-98.

Baker, H. Kent - Farrelly, Gail E. - Edelman, Richard B. (1985), “ A Survey of Management Views on Dividend Policy”, Financial Management, Vol. 14, Issue 3, pp. 78-84.

Baker, Malcolm - Nagel, Stefan - Wurgler, Jeffrey (2007), “ The Effect of Dividends on Consumption ”, Brookings Papers on Economic Activity, 1, pp. 277-291.

Bar-Yosef, Sasson - Huffman, Lucy (1986), “ The Information Content of Dividends: A Signaling Approach ”, Journal of Financial and Quantitative Analysis, Vol. 21, Issue 1, pp. 47-58.

Benartzi, Shlomo - Michaely, Roni - Thaler, Richard (1997), “ Do Changes in Dividends Signal The Future or The Past?”, The Journal of Finance, Vol. 52, Issue 3, pp. 10071034. 
Berle, Adolf - Means, Gardiner (1932), Private Property And The Modern Corporation, New York: MacMillan.

Bernheim, B. Douglas - Wantz, Adam (1992), “ A Tax-based Test of The Dividend Signaling Hypothesis”, No. w4244, National Bureau of Economic Research (NBER).

Brava, Alon - Graham, John R. - Harvey, Campbell - Michaely, Roni (2005), “ Payout Policy in The 21st Century ”, Journal of Financial Economics, Vol. 77, Issue 3, pp. 483-527.

Brickley, James A. (1983), “ Shareholder Wealth, Information Signaling And The Specially Designated Dividend: An Empirical Study ”, Journal of Financial Economics, Vol. 12, Issue 2, pp. 187-209.

Brittain, John A. (1964), “ The Tax Structure And Corporate Dividend Policy”, The American Economic Review, Vol. 54, Issue 3, pp. 272-287.

Brittain, John A. (1966), “ Corporate Dividend Policy ”, Brookings institution.

Brooks, Raymond M. (1996), “ Changes in Asymmetric Information at Earnings And Dividend Announcements ”, Journal of Business Finance \& Accounting, Vol. 23, Issue 3, pp. 359-378.

Chan, Konan - Ikenberry, David - Lee, Inmoo (2000), “ Do Managers Knowingly Repurchase Stock on The Open-market ”, Unpublished working paper, Rice University.

Chateau, J. P. D. (1979), “ Dividend Policy Revisited: Within-And Out-Of-Sample Tests ”, Journal of Business Finance And Accounting, Vol. 6, Issue 3, pp. 355-370.

Chay, Jong-Bum - Suh, Jungwon (2005), “ Cross-Sectional Determinants of Dividend Payments: International Evidence ”, Sungkyungkwan University, pp. 3-53.

Chemmanur, Thomas J. - Tian, Xuan (2014), “ Communicating Private Information to The Equity Market Before a Dividend Cut: An Empirical Analysis ”, The Journal of Financial And Quantitative Analysis, Vol. 49, Issue 5-6, pp. 1167-1199.

DeAngelo, Harry - DeAngelo, Linda (1990), “ Dividend Policy And Financial Distress: An Empirical Investigation of Troubled NYSE Firms”, The Journal of Finance, Vol. 45, Issue 5, pp. 1415-1431.

DeAngelo, Harry - DeAngelo, Linda (2006), “ The Irrelevance of The MM Dividend Irrelevance Theorem ”, Journal of Financial Economics, Vol. 79, Issue 2, pp. 293-315.

DeAngelo, Harry - DeAngelo, Linda - Skinner, Douglas J. (1996), “ Reversal of Fortune Dividend Signaling And The Disappearance of Sustained Earnings Growth ”, Journal of Financial Economics, Vol. 40, Issue 3, pp. 341-371.

DeAngelo, Harry - DeAngelo, Linda - Skinner, Douglas J. (2000), “ Special Dividends And The Evolution of Dividend Signaling ”, Journal of Financial Economics, Vol. 57, Issue 3, pp. 309-354. 
DeAngelo, Harry - DeAngelo, Linda - Skinner, Douglas J. (2004), “ Are Dividends Disappearing? Dividend Concentration And The Consolidation of Earnings ”, Journal of Financial Economics, Vol. 72, Issue 3, pp. 425-456.

Denis, David J. - Denis, Diane K. - Sarin, Atulya (1994), “ The Information Content of Dividend Changes: Cash Flow Signaling, Overinvestment, And Dividend Clienteles ”, Journal of Financial And Quantitative Analysis, Vol. 29, Issue 4, pp. 567-587.

Dewenter, Kathyrn L. - Warther, Vincent A. (1998), “ Dividends, Asymmetric Information, and Agency Conflicts: Evidence from a Comparison of the Dividend Policies of Japanese and U.S. Firms ”, Vol. 53, Issue 3, pp. 879-904.

Ellili, Nejla (2011), “ Ownership Structure, Financial Policy And Performance of The Firm: US Evidence ”, Vol. 6, Issue 10, pp. 80-93.

Fama, Eugene F. (1974), “ The Empirical Relationships Between The Dividend And Investment Decisions of Firms ”, The American Economic Review, Vol. 64, Issue 3, pp. 304-318.

Fama, Eugene F. - Babiak, Harvey (1968), “ Dividend policy: An Empirical Analysis ”, Journal of The American Statistical Association, Vol. 63, Issue 324, pp. 1132-1161.

Fama, Euegene F. - French, Kenneth R. (2001), “ Disappearing Dividends: Changing Firm Characteristics or Lower Propensity to Pay? ”, Journal of Financial Economics, Vol. 60, Issue 1, pp. 3-43.

Frankfurter, George M. - Wood, Bob (2002), “ Dividend Policy Theories And Their Empirical Tests ”, International Review of Financial Analysis, Vol. 11, Issue 2, pp. 111-138.

Fuller, Kathleen - Thakor, Anjan (2002), “ Signaling, Free Cashflows and Nonmonotonic Dividends ", Working Papers Series, University of Georgia and University of Michigan Business School.

Glen, Jack D. - Karmokolias, Yannis - Miller, Robert R. - Shah, Sanjay (1995), “ Dividend Policy And Behavior in Emerging Markets: To Pay or Not to Pay ”, The World Bank.

Grinstein, Yaniv - Michaely, Roni (2005), “ Institutional Holdings And Payout Policy ”, The Journal of Finance, Vol. 60, Issue 3, pp. 1389-1426.

Grullon, Gustavo - Michaely, Roni (2002), “ Dividends, Share Repurchases, And The Substitution Hypothesis ”, The Journal of Finance, Vol. 57, Issue 4, pp. 1649-1684.

Grullon, Gustavo - Michaely, Roni - Benartzi, S. - Thaler, Richard H. (2005), “ Dividend Changes do Not Signal Changes in Future Profitability ”, The Journal of Business, Vol. 78, Issue 5, pp. 1659-1682. 
Hasan, Mudassar - Ahmad, Muhammad I. - Rafiq, Yasir - Rehman, Ramiz U. (2015), “ Dividend Payout Ratio And Firm's Profitability: Evidence From Pakistan ”, Theoretical Economics Letters, Vol. 5, pp. 441-445.

Hassan, M. Kabir - Farhat, Joseph - Al-Zubi, Bashir (2003), “ Dividend Signaling Hypothesis And Short-Term Asset Concentration of Islamic Interest Free Banking ”, Islamic Economic Studies, Vol. 11, Issue 1, pp. 1-30.

Healy, Paul M. - Palepu, Krishna G. (1988), “ Earnings Information Conveyed by Dividend Initiations And Omissions ”, Journal of Financial Economics, Vol. 21, Issue 2, pp. 149-175.

Jagannathan, Murali - Clifford Stephens P. - Weisbach, Michael S. (2000), “ Financial Flexibility And The Choice Between Dividends And Stock Repurchases ”, Journal of Financial Economics, Vol. 57, Issue 3, pp. 355-384.

Jensen, Michael C. - Meckling, William H. (1976), “ Theory of The Firm: Managerial Behavior, Agency Costs And Ownership Structure ”, Journal of Financial Economics, Vol. 3, Issue 4, pp. 305-360.

Jensen, Michael C. (1986), “ Agency Costs of Free Cash Flow, Corporate Finance, and Takeovers ”, The American Economic Review, Vol. 76, Issue 2, pp. 323-329.

John, Kose - Kalay, Avner (1982), “ Costly Contracting And Optimal Payout Constraints ”, The Journal of Finance, Vol. 37, Issue 2, pp. 457-470.

Kane, Alex - Lee, Young K. - Marcus, Alan (1984), “ Earnings And Dividend Announcements: Is There a Corroboration Effect? ”, The Journal of Finance, Vol. 39, Issue 4, pp. 1091-1099.

Kato, Kiyoshi - Loewenstein, Uri (1995), “ The Ex-Dividend-Day Behavior of Stock Prices: The Case of Japan ”, The Review of Financial Studies, Vol. 8, Issue 3, pp. 817-847.

Kaymaz, Ozgur (2010), “ Şirket Temettu Politikasinda Sinyalizasyon Teorisi ve Bir IMKB Uygulamasi (Signalization Theory in Corporate Dividend Policy and a BIST -Istanbul Stock Exchange- Application) ”, Unpublished doctoral dissertation, Istanbul University, Istanbul, Turkey.

Khang, Kenneth - King, Dolly (2002), “ Is Dividend Policy Related to Information Asymmetry: Evidence From Insider Trading Gains ”, AFA 2003 Washington, DC Meetings.

Lang, Larry H. - Litzenberger, Robert H. (1989), “ Dividend Announcements: Cash Flow Signaling vs. Free Cash Flow Hypothesis? ”, Journal of Financial Economics, Vol. 24, Issue 1, pp. 181-191.

Lasfer, M. Ameziane (1996), “ Taxes And Dividends: The UK Evidence ”, Journal of Banking And Finance, Vol. 20, Issue 3, pp. 455-472. 
Laux, Paul - Starks, Laura T. - Yoon, Pyung S. (1998), “ The Relative Importance of Competition And Contagion in Intra-Industry Information Transfers: An Investigation of Dividend Announcements ”, Financial Management, Vol. 27, Issue 3, pp. 5-16.

Lintner, John (1956), “ Distribution of Incomes of Corporations Among Dividends, Retained Earnings, And Taxes ”, The American Economic Review, Vol. 46, Issue 2, pp. 97113.

Marsh, Terry A. and Merton, Robert C. (1987), “ Dividend Behavior For The Aggregate Stock Market ”, Journal of Business, Vol. 60, Issue 1, pp. 1-40.

McDonald, John G. - Jacquillat, Bertrand - Nussenbaum, Maurice (1975), “ Dividend, Investment And Financing Decisions: Empirical Evidence on French Firms ”, Journal of Financial And Quantitative Analysis, Vol. 10, Issue 5, pp. 741-755.

Mehta, Anupam. (2012), “ An Empirical Analysis of Determinants of Dividend Policy Evidence from the UAE Companies ”, Global Review of Accounting and Finance, Vol. 3, Issue 1, pp. 18-31.

Mileva, Elitza (2007), “ Using Arellano-Bond Dynamic Panel GMM Estimators in Stata ”, Unpublished Manuscript, Economics Department, Fordham University, New York.

Myers, Stewart C. (1977), “ Determinants of Corporate Borrowing ”, Journal of Financial Economics, Vol. 5, Issue 2, pp. 147-175.

Nenu, Elena A. - Vintila, Georgeta - Gherghina, Stefan C. (2018), “ The Impact of Capital Structure on Risk And Firm Performance: Empirical Evidence For The Bucharest Stock Exchange Listed Companies ”, International Journal of Financial Studies, Vol.6, Issue 41, pp. 1-29.

Nissim, Doron - Ziv, Amir (2001), “ Dividend Changes And Future Profitability ”, The Journal of Finance, Vol. 56, Issue 6, pp. 2111-2133.

Ofer, Aharon R. - Thakor, Anjan V. (1987), “ A Theory of Stock Price Responses to Alternative Corporate Cash Disbursement Methods: Stock Repurchases And Dividends ”, The Journal of Finance, Vol. 42, Issue 2, pp. 365-394.

Parsian, Hosein - Koloukhi, Amir S. (2014), “ A Study on The Effect of Free Cash Flow And Profitability Current Ratio on Dividend Payout Ratio: Evidence From Tehran Stock Exchange ”, Management Science Letters, Vol. 4, pp. 63-70.

Penman, Stephen H. (1983), “ The Predictive Content of Earnings Forecasts And Dividends ”, The Journal of Finance, Vol. 38, Issue 4, pp. 1181-1199.

Pruitt, Stephen W. - Gitman, Lawrence J. (1991), “ The Interactions Between The Investment, Financing, And Dividend Decisions of Major US Firms ”, Financial Review, Vol. 26, Issue 3, pp. 409-430. 
Rehman, Abdul - Haruto, Takumi (2012), “ Determinants of Dividend Payout Ratio: Evidence From Karachi Stock Exchange ”, Journal of Contemporary Issues in Business Research, Vol. 1, Issue 1, pp. 20-27.

Shevlin, Terrence J. (1982), “ Australian Corporate Dividend Policy: Empirical Evidence ”, Accounting And Finance, Vol. 22, Issue 1, pp. 1-22.

Sinha, Meenakshi - Sunder, Jayanthi - Bhaskaran, Swaminathan (2006), “ Payout Policy And Cost of Capital ", Working Paper, Available at SSRN: https://ssrn.com/abstract=620382 or http://dx.doi.org/10.2139/ssrn.620382

Valipour, Hashem - Rostami, Vahab - Mahdi, Salehi (2009), “ Asymmetric Information And Dividend Policy in Emerging Markets: Empirical Evidences from Iran ”, International Journal of Economics and Finance, Vol. 1, Issue 1, pp. 203-211.

Watts, Ross (1973), “ The Information Content of Dividends ”, The Journal of Business, Vol. 46, Issue 2, pp. 191-211.

Williams, Joseph (1988), “ Efficient Signaling With Dividends, Investment, And Stock Repurchases ”, The Journal of Finance, Vol. 43, Issue 3, pp. 737-747. 